\title{
Developing a Green Bonds Market: Lessons from China
}

\author{
Lin $\operatorname{Lin}^{1} \cdot$ Yanrong Hong ${ }^{2}$
}

Accepted: 13 December 2021 / Published online: 21 February 2022

(c) T.M.C. Asser Press 2022

\begin{abstract}
Since its launch in 2016, China's green bonds market has amassed a significant size and is currently ranked as the second largest in the world. This paper takes a pioneering step to analyze how a transitional economy can develop a burgeoning green bonds market within a short period, using China as a case study. It concludes that the Chinese government plays an instrumental but also evolving role in this process. The carefully designed use of government mechanisms in the context of unique government structures can constructively facilitate the growth of a green bonds market. At the emerging stage of this unique market, the government can play an active role in designing a conducive regulatory environment through law and policy, providing the necessary financial infrastructure and appropriate incentives for investors and green bond issuers. Government intervention is warranted at this stage, given the special characteristics of the green market, in particular, the desired positive externalities on environmental protection and climate change. In China, such a regime is implemented with a focus on inter-ministerial, central-local and international collaboration, centralized policy-making, and alignment of green goals with performance assessment of local officials. However, as the green bonds market matures, this paper suggests a transition towards a market-oriented model where the government should assume a limited role, providing funding and monitoring, and letting market forces play a greater role in achieving market efficiency. Unleashing the potential of market forces can mitigate several of the challenges faced by a top-down approach. This paper also examines the challenges that have surfaced in China, including lowquality information disclosure and under-utilization of green bonds financing by private enterprises. In response, several solutions are proposed to address these specific challenges.
\end{abstract}

Keywords China's green bonds market · Role of government - Sustainability · Green finance $\cdot$ Green bond standard - Sustainability information disclosure

Lin Lin

lawll@nus.edu.sg

$凶$ Yanrong Hong hyr@pku.edu.cn

Extended author information available on the last page of the article 


\section{Introduction}

According to the International Capital Market Association (ICMA) green bonds are 'any type of bond instrument where the proceeds will be exclusively applied to finance or re-finance in part or in full new and/or existing eligible green projects and which are aligned with the four core components of the Green Bond Principles'. ${ }^{1}$ The same definition is applied in the Climate Bonds Standard and Certification Scheme developed by the Climate Bonds Initiative (CBI), which also provides certifications to green bonds based on pre-issuance and post-issuance requirements. ${ }^{2}$ The EU Green Bond Standard defines an EU Green Bond in a similar way requiring that the proceeds shall be exclusively used to finance or refinance in part or in full new and/or existing Green Projects. ${ }^{3}$

A vibrant green bonds market is desirable for China because it promotes environmental protection and sustainability even amid rapid economic development and introduces diversified portfolios into the capital market to alleviate climate risks. Over the past 40 years of reform and opening up, economic development in China has made world-renowned achievements. China's GDP exceeded RMB 100 trillion for the first time in 2020. ${ }^{4}$ However, along with rapid economic development, China is also facing serious damage to the living environment. ${ }^{5}$ In recent years, the government has resolved to pursue environmental protection and sustainable development as an important national strategy and to mitigate some of the negative impacts brought about by decades of rapid growth. As a result, China specifically proposed the national strategy of achieving 'ecological civilization' in $2015^{6}$ and incorporated a green philosophy into the five major development concepts. ${ }^{7}$ It then began to explore reforms geared towards green and low-carbon economic development, becoming an active implementer of the climate control goals ${ }^{8}$ proposed by the United Nations Framework Convention on Climate Change, the Paris Agreement, and other related international conventions.

\footnotetext{
1 International Capital Market Association (2018), p 3 [emphasis added]. The four core components are: (1) use of proceeds; (2) process for project evaluation and selection; (3) management of proceeds; and (4) reporting.

${ }^{2}$ CBI (2019), p 8.

3 EU Technical Expert Group on Sustainable Finance (2019a), Annex 1, Section 3 Definition of an EU Green Bond.

4 State Council (2021).

5 See, for instance, Kan (2009).

6 The Opinions of the Central Committee of the Communist Party of China and the State Council on Accelerating the Construction of Ecological Civilization [中共中央、国务院关于加快推进生态文明 建设的意见], Central Committee of the CPC (25 Apr 2015); General Plan for the Reform of the Ecological Civilization System [生态文明体制改革总体方案], Central Committee of the CPC (21 Sep 2015); this became the top-level design plan to guide China's development of the green economy.

7 The 13th 5-year plan for the National Economic and Social Development of the People's Republic of China [中华人民共和国国民经济和社会发展第十三个五年规划纲要], National People's Congress (3 March 2016), hereinafter referred to as the '13th 5-Year Plan', puts forward the five new development concepts, i.e., 'innovation, coordination, green economy, openness and sharing'.

8 I.e., to meet the objectives enshrined in the Paris Agreement, limiting the global temperature increase this century to below $2{ }^{\circ} \mathrm{C}$ above pre-industrial levels.
} 
In September 2020, President Xi Jinping announced the '30/60 goal' at the United Nations General Assembly, according to which China aims to peak carbon emission by 2030 and reach carbon neutrality by $2060 .{ }^{9}$ More specifically, at the 5 th Anniversary of the Paris Agreement at the Climate Ambition Summit on 12 December 2020 he announced that

China will lower carbon dioxide emissions per unit of GDP by 65\% from 2005 levels, increase the share of non-fossil fuels in primary energy consumption to around $25 \%$ by 2030 , increase forest stock by 6 billion cubic meters above 2005 levels and bring the total installed capacity of wind and solar power to over $1200 \mathrm{GW}$ by $2030 .^{10}$

At the same time, a report by the Climate Policy Initiative suggests that a sizeable investment of RMB 3-4 trillion per year is needed for China to meet its commitments under the Paris Agreement. ${ }^{11}$

In order to implement China's '30/60 goal', the 14th 5-year plan that started in 2021 aims to accelerate low-carbon development in China. ${ }^{12}$ The State Council's Guiding Opinions on Accelerating the Establishment of a Sound Green, Low-Carbon Circular Economic System released on 2 February 2021 reiterate the importance of establishing a sound green, low-carbon circular economic system, and includes comprehensive guidelines. ${ }^{13}$ The guidelines include the accelerated development of green finance, the strengthening of legal and regulatory support, and the improvement of green standards, the green certification system and the statistical monitoring system. ${ }^{14}$ The setting of such high-level policy goals sends a strong signal to the market and spurs market participants to actively initiate green projects and raise funds in green finance. ${ }^{15}$ The State Council further issued the Guidance for Carbon Dioxide Peaking, and Carbon Neutrality in Full and Faithful Implementation of the New Development Goals on 22 September 2021, detailing the principles and methods for achieving the '30/60 goal'. 16

\footnotetext{
9 Myers (2020).

10 World Resources Institute (2020).

11 Climate Policy Initiative (2020b), p 1.

12 The Proposal of the Central Committee of the Communist Party of China on Formulating the 14th Five-Year Plan for National Economic and Social Development and the Visionary Goals for 2035 [中 共中央关于制定国民经济和社会发展第十四个五年规划和二○三五年远景目标的建议], Central Committee of the CPC (29 Oct 2020), proposed goals and initiatives such as 'achieving new progress in ecological civilization construction' and 'accelerating the promotion of green and low-carbon development'.

13 State Council's Guiding Opinions on Accelerating the Establishment of a Sound Green, Low-Carbon Circular Economic System [国务院关于加快建立健全绿色低碳循环发展经济体系的指导意见], State Council (2 Feb 2021), State Council No. 4 of [2021].

14 See for an English analysis Wang and Huang (2021).

15 Ma (2017); see also Wilkins (2021).

16 Guidance for Carbon Dioxide Peaking, and Carbon Neutrality in Full and Faithful Implementation of the New Development Goals [中共中央、国务院关于完整准确全面贯彻新发展理念做好碳达峰碳中 和工作的意见], Central Committee of the CPC and State Council (22 Sep 2021).
} 
Under this context, the establishment of the green bonds market assumes crucial significance in China's ongoing economic transformation from an energy-andpollution-intensive economy to a resource-conserving and environment-friendly economy. With the accelerating pace of adopting low-carbon economic activities, the improvement of the green financial system, including green bonds, and its corresponding market operation mechanism becomes increasingly urgent. Accordingly, green bonds are considered by the Chinese government as an effective financial instrument to facilitate this economic transformation. As a result, developing the green bonds market has been a part of the central government's top-level green finance initiative. ${ }^{17}$ CGN Wind Power Co., Ltd. first issued a RMB 1 billion medium-term note (i.e., a debt financing instrument of non-financial enterprises), with interest rates linked to carbon emission reduction benefits, in the Interbank Bond Market in May 2014. ${ }^{18}$ In January 2016, the Industrial and Commercial Bank of China was approved to issue RMB 10 billion of green financial bonds in the Interbank Bond Market, ${ }^{19}$ marking the official launch of green bonds in China. ${ }^{20}$

Despite its relative youth compared to its counterpart in the EU, where the European Investment Bank issued the first green bonds in the world - the Climate Awareness Bonds - in 2007, ${ }^{21}$ China's green bonds market developed at a rapid pace in the past few years. ${ }^{22}$ In 2016, China became one of the largest issuers of green bonds in the world. ${ }^{23}$ According to statistics from the CBI and China Central Depository and Clearing Research Centre (CCDC Research), Chinese issuers issued a total of RMB 386.2 billion (US\$ 55.8 billion) of labeled green bonds in 2019 in both domestic and international markets, making China the largest source of labeled green bonds. ${ }^{24}$ By the end of 2019, China's domestic green bonds market had a total outstanding

\footnotetext{
17 China proposed the strategic initiative of 'establishing a green finance system' in the General Plan for the Reform of the Ecological Civilization System in 2015, see supra note 6. In 2016, the People's Bank of China (PBOC) and six ministries and commissions jointly issued the Guiding Opinions on Building a Green Financial System [中国人民银行、财政部、发展改革委等关于构建绿色金融体系的指导意 见] (31 Aug 2016), which were enacted to establish a green finance system. See, in general, Green China's Financial System Study Group of DRC (2016), stating that 'green bonds have become an important vehicle for green finance, as they are more easily incorporated into investment portfolios by institutional investors as a medium and long-term financial product'.

18 Hong (2016).

19 Zheng (2016).

20 The operation of these green financial bonds follows the Green Bond Principles issued by the ICMA and the Climate Bonds Standard.

21 International Finance Corporation (2016), p 1.

22 Zhang (2020), p 1.

23 Shi and Wang (2018), p 32.

${ }^{24} \mathrm{CBI}$ and CCDC Research (2020), p 3. According to the CBI, an aligned green bond in the Chinese market is a green bond that has been approved for issuance by the regulator or has been registered on the bond exchange with a full name that includes the word 'green' in the label. Green bonds are considered to be aligned green bonds as defined by the CBI only if they invest at least $95 \%$ of the funds raised in green assets or projects that are consistent with the Climate Bonds Taxonomy. Verification of Certified Climate Bonds involves third-party assessments that are conducted by approved verifiers authorized by the CBI in accordance with the Climate Bonds Standard and industry standards, certifying that the funds raised are used to limit global warming to below $2{ }^{\circ} \mathrm{C}$.
} 
amount of RMB 977.2 billion (US $\$ 140$ billion). ${ }^{25}$ As of March 2021, China leads the world in the value of outstanding green loans at about US\$ 2 trillion. ${ }^{26}$ It is also the second largest green bonds market in the world ranking only after the United States. ${ }^{27}$ Such a rapid expansion of the green bonds market contributed significant investment to important sectors such as energy, transport and environmental protection, paving the way for China's transition to a low-carbon green economy (Fig. 1). ${ }^{28}$

However, the government-led approach in building a green bonds market in China comes in contrast with the laissez-faire approach which entrusts market forces alone to develop the green bonds market. ${ }^{29}$ For instance, scholars have argued that the governance regime of the green bonds market in the United States is largely established by private ordering. ${ }^{30}$ Meanwhile, the approach in the EU is somewhere in between government intervention and private ordering. This is demonstrated by the enactment of the EU Taxonomy Regulation ${ }^{31}$ and the EU Sustainable Finance Disclosure Regulation, ${ }^{32}$ where the regulators set certain bounds and rules for market activities to take place in a guided way. Going forward, while it is unlikely for China to straightly switch to the US style focusing primarily on private ordering, it does have a lot to learn from the EU experience.

These varying approaches beg the paradoxical question of what the limitations and drawbacks of industrial policies and centralized government strategies are. Against this backdrop, this paper takes a pioneering step to analyze how a transitional economy can develop a burgeoning green bonds market within a short period, using China as a case study. Although there is some literature discussing the role

\footnotetext{
${ }^{25}$ RMB 628.2 billion (US $\$ 90$ billion) of the total outstanding amount meets both the CBI definition and the Chinese green bonds definition, and another RMB 349 billion ( $\$ 50$ billion) of bonds only meet the Chinese green bonds definition. Exchange rate conversions for the above data may vary, as the CBI uses the actual exchange rate on the date of issuance for each bond. See CBI and CCDC Research (2020), p 12.

${ }^{26}$ Brown (2021).

${ }^{27} \mathrm{CBI}$ and CCDC Research (2021), p 3.

${ }^{28}$ Kidney et al. (2015), pp 249-253.

${ }^{29} \mathrm{Ma}(2017)$.

${ }^{30}$ See, for example, Park (2018) (arguing that the green bonds market in the United States is largely a legacy of private governance and the role of government regulators is largely missing); see for another example MacLeod and Park (2011) (describing the role of investor-based coalitions in environmental governance based on political science scholarship).

${ }^{31}$ Regulation (EU) 2020/852 of the European Parliament and of the Council of 18 June 2020 on the establishment of a framework to facilitate sustainable investment, and amending Regulation (EU) 2019/2088.

32 Regulation (EU) 2019/2088 of the European Parliament and of the Council of 27 November 2019 on sustainability-related disclosures in the financial services sector.
} 
of government in the green bonds market, ${ }^{33}$ there is little legal literature analyzing this issue in the context of China. ${ }^{34}$ While there are a number of factual reports by research institutes shedding light on this issue, relatively less academic analysis is available. ${ }^{35}$ This paper therefore aims to fill this literature gap. It also provides a timely reflection on the desirability of a government-steered green bonds market versus private ordering and their relative pros and cons.

To do this, three pressing questions need to be answered. First, why and how is China able to effectively develop a green bonds market within a short period of time? Second, what are some of the challenges in developing its green bonds market, and how might these be addressed through regulatory reform? Third, which parts of this analysis are unique to the Chinese context and what is the general advice applicable to other growing markets? These questions will be of special importance to policymakers and legislators in countries looking to develop their green bonds market or encountering difficulties in developing their green bonds market.

This paper suggests that a government can help to develop a green bonds market by playing an instrumental but also evolving role. First, at the emerging stage of this unique market, the government can play a more active role in designing a conducive regulatory environment through law and policy, providing the necessary financial infrastructure and appropriate incentives for investors and green bond issuers. Government intervention is warranted at this stage, given the unique features of the green market, in particular, the desired positive externalities on environmental protection and climate change. In China, such a regime is implemented with a focus on inter-ministerial, central-local collaboration, centralized policy-making, and alignment of green goals with performance assessment of local officials. Second, as the green bonds market matures with sophisticated market players and a wellestablished institutional and financial infrastructure, the government should assume a limited role, providing funding and monitoring, and letting market forces play a greater role in achieving market efficiency. Unleashing the potential of market forces can mitigate several of the challenges faced by a top-down approach.

The framework of this paper is as follows. Section 2 introduces the unique Chinese experience in developing a green bonds market in China through a top-down approach, inter-ministerial synergy, and central-local cooperation. Section 3 analyzes the special characteristics of China's green bonds market, highlighting the existing differences with international standards in important aspects such as the use of proceeds, sustainability information disclosure, and credit ratings, while making

\footnotetext{
33 See, for example, Park (2018) (examining governance gaps in the green bonds market where there is an absence of government regulation); Freeburn and Ramsay (2020) (examining legal and policy issues present in the green bonds market and identifying how some of these issues could potentially be solved by the government and law).

34 Some positive examples that have been written on this topic include Zhang (2020) (analyzing the definitional divergence in Chinese regulations governing China's green bonds market), Kidney et al. (2015) (highlighting the importance of green bonds in China and making a few policy recommendations to develop the market in China) and Ma et al. (2019) (discussing key features of China's green bonds market and the role of the government in developing the market). However, in general there is a shortage of academic writing on this topic and such positive examples are limited in number.

35 See, for example, CBI (2017), CBI and CCDC Research (2020) and Climate Policy Initiative (2020b).
} 


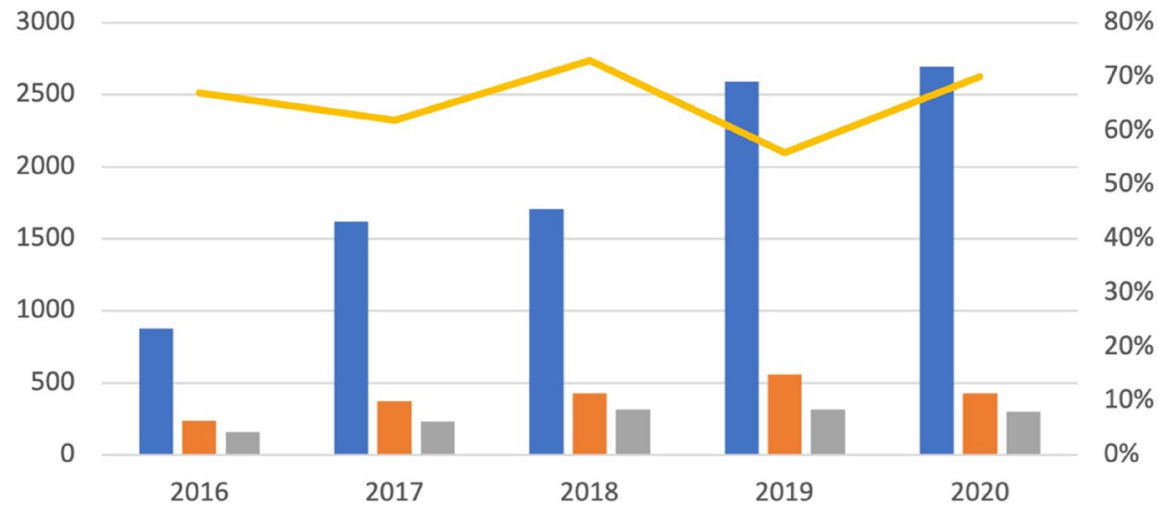

\section{All labeled bonds aligned with CBI definitions of 'green' \\ China labeled green bonds \\ Chinese green bonds that align with $\mathrm{CBI}$ definitions \\ Percentage of Chinese green bonds that align with $\mathrm{CBI}$ definitions}

Fig. 1 Amount of China's green bond issuance in 2016-2020 (in billion USD). The data is compiled by the authors according to the CBI green definition and China's domestic green definition. It is also based on the statistics from CBI, Lianhe Equator Environmental Impact Assessment and China Bond Rating. The sources include CBI and CCDC Research (2017), CBI and CCDC Research (2018), CBI and CCDC Research (2019), CBI and CCDC Research (2020), and Jones (2021).

the case for greater convergence. Section 4 further examines the challenges that have surfaced in China, including under-utilization of green bonds financing by private enterprises, potential misallocation and waste of resources, and the need for greater retail investor education. It proposes several solutions to these specific challenges and, lastly, makes the case for a gradual transition from a government-oriented approach towards a market-oriented one. Section 5 concludes.

\section{The Unique Chinese Experience in Establishing a Government-led Green Bonds Market}

This Section explores in detail the unique Chinese experience in establishing a green bonds market with the help of high-level government policy guidance and intervention. It begins by introducing the different types of green bonds in China and goes on to explain how China is able to tap into a combination of top-down and bottom-up approaches in terms of top-level design, inter-ministerial synergy, and central-local coordination in taking a concerted approach in developing the green bonds market. In addition, the importance of tying sustainability goals with the performance evaluation of officials and the evolving role of the courts are also analysed. The authors note here that the Chinese experience is sui generis due to its political and social 
constructs and not easily transferable to other jurisdictions where, for example, the government does not have a strong influence or incentive to guide the development of the market.

\subsection{Multiple Types of Green Bonds in China}

There are various types of green bonds in China and they are launched and administered by different regulatory agencies. ${ }^{36}$ There are broadly three categories, namely green corporate bonds administered by the China Securities Regulatory Commission (CSRC), green enterprise bonds administered by the National Development and Reform Commission (NDRC), and green medium-term notes administered by the People's Bank of China (PBOC) and registered by the National Association of Financial Market Institutional Investors (NAFMII). ${ }^{37}$ Unlike financial institution bonds, these three types of green bonds are ordinary corporate bonds financed on the basis of the issuer's commercial credit.

Chinese financial institutions have also issued green bonds securitized by credit assets in the Interbank Bond Market. ${ }^{38}$ Non-financial corporations have issued green asset-backed securities and green asset-backed notes in exchange markets and the Interbank Bond Market respectively. ${ }^{39}$ These green asset-backed financial instruments are based on assets that can generate cash flow returns in the future, and they are different from financial institution bonds or general green corporate bonds financed on the basis of issuers' credit.

Some local government financing vehicles (LGFVs, i.e., financing firms) have issued green bonds, which are often referred to as LGFV green bonds, in the market under the domestic bonds system. ${ }^{40}$ On 18 June 2019, Ganjiang New Area of Jiangxi Province issued its first RMB 300 million green bond with a fixed maturity of 30 years, the first labeled municipal green bond from China, ${ }^{41}$ further enriching the type of green bonds and their issuers in China.

In addition, the Chinese government has also established various channels to facilitate greater access to the domestic bonds market by foreign investors. At

\footnotetext{
${ }^{36}$ There is a large non-labeled green bonds market in China, i.e., bonds that are not specifically labeled as green bonds but raise funds for green industries. In this market, local governments (including local state-owned enterprises and local government financing platform companies) are the most important issuers, and the funds raised are mainly invested in the clean transportation sector. According to statistics, from 2009 to 2020, a total of 3,368 non-labeled green bonds were issued in China's bond market, with an issue size of about RMB 10.32 trillion, RMB 6.12 trillion of which was used for green project investment. See Yun (2021).

37 The green project standard set by the Green Finance Professional Committee of the Chinese Society of Finance applies to the former two types, while the green project standard set by the Development and Reform Commission applies to the last type. See also Climate Policy Initiative (2020a), p 5, Table 2.

${ }^{38}$ See, for example, CBI and SynTao Green Finance (2017), p 4.

${ }^{39}$ Ibid., p 6.

40 The volumes of LGFV green bonds have increased by four times since the inaugural issuance by Jiangsu Guoxin Investment, an investment and holding company of the State-owned Assets Supervision and Administration Commission of Jiangsu Province, in 2016. The surge was primarily driven by provincial LGFVs. See CBI and CCDC Research (2020), p 5.

${ }^{41}$ Jiang and Lei (2019).
} 
present, the main channels for international investors to invest in China's green bonds market include: (1) Qualified Foreign Institutional Investors (QFII); (2) Renminbi Qualified Foreign Institutional Investors (RQFII); ${ }^{42}$ (3) direct access to the Chinese Interbank Bond Market; ${ }^{43}$ and (4) the Bond Connect programme. ${ }^{44}$

Since Goldwind Science and Technology Co., Ltd. issued its first green bond of US\$ 300 million with a maturity of 3 years on the Hong Kong Stock Exchange (HKEx) on 18 July $2015,{ }^{45}$ China's overseas green bonds market has achieved a steady growth. As of 2019, Chinese entities have issued 66 green bonds overseas for a total amount of about RMB 212.995 billion, the issuers being policy banks, commercial banks, non-financial corporates, etc. ${ }^{46}$ At a news conference on 19 July 2021, the NDRC reported 16 overseas green bonds issuances, with a total amount of about US\$ 8.5 billion in 2020, marking a significant increase. ${ }^{47}$ For the exchange market, a number of international trading centers are included, such as the HKEx, the Luxembourg Stock Exchange, the London Stock Exchange and the Singapore Exchange, with the US dollar as the main issuance currency. ${ }^{48}$ In terms of the use of funds raised, in addition to meeting the requirement of being green, they also feature targeted support for China's national strategies, such as the 'Belt and Road' bonds and Guangdong-Hong Kong-Macao Greater Bay Area bonds. ${ }^{49}$

Among the channels used, the Bond Connect programme is currently the most convenient channel for international investors to invest in the domestic green bonds market. ${ }^{50}$ The Hong Kong-Mainland Bond Market Connect allows investors from mainland China and overseas to trade bonds in each other's markets through an infrastructure link established in Hong Kong, which includes the 'Northbound Connect' and the 'Southbound Connect'. 51 This means international investors can invest in bonds in the domestic Interbank Bond Market through an account opened for them by a custodian in Hong Kong, which in turn will open a corresponding account in mainland China through a domestic custodian. ${ }^{52}$ Given the proximity of Hong

\footnotetext{
42 The People's Bank of China and the Foreign Exchange Administration issued a document in September 2020 to abolish the restrictions on the investment quota of QFII and RQFII, while the restrictions on the pilot countries and regions of RQFII were also abolished, and the policies regarding different channels for foreign institutional investors to invest in the interbank market were, in principle, basically converged. See State Administration of Foreign Exchange (2020).

43 See People's Bank of China Announcement [2016] No. 3 [中国人民银行公告 (2016) 第3号], PBOC (24 Feb 2016), http://www.pbc.gov.cn/tiaofasi/144941/144959/3021203/index.html (accessed 31 Nov 2021). This announcement stated that the 'direct access to the Chinese Interbank Bond Market' route requires investors to first register with the People's Bank of China and then invest through a qualified domestic correspondent bank.

44 Bond Connect (2021a).

45 Renewables Now (2015).

46 Liao and Yun (2020), Section II.

47 National Development and Reform Commission (2021).

48 See supra note 46, Section II (2).

49 Ibid., Section II (3).

50 Qian and Lu (2018), p 84.

51 People's Bank of China (2017).

52 Bond Connect (2021b).
} 
Kong's existing market infrastructure to the international market, through the Bonds Connect programme, international investors can make use of Hong Kong's market infrastructure to invest in China's domestic bond market. This programme not only reduces the burden on international investors to understand and follow the specific rules and procedures of the Chinese Interbank Bond Market, but also avoids transaction costs. ${ }^{53}$

The relaxation of investor eligibility requirements under the Bonds Connect programme means that more small and medium-sized foreign investors are able to access the domestic market. ${ }^{54}$ There are also no investment quotas for small and medium-sized foreign investors under the Bond Connect programme. Through the programme, more international investors have direct access to the primary and secondary markets, increasing the liquidity of China's green bonds market. ${ }^{55}$ It also allows mainland investors easy access to foreign bonds in Hong Kong, providing them with additional means to diversify their portfolios. ${ }^{56}$

\subsection{A Top-Level Design}

The Chinese government takes the lead in developing the green financial system, which includes green bonds. ${ }^{57}$ The central government believes that adopting a top-down approach and the so-called 'forced institutional change' in establishing the green bonds market in China is necessary. ${ }^{58}$ First, it can help China to efficiently establish a green financial system for the transformation to a green low-carbon economy and the construction of ecological civilization, instead of waiting for the market to develop organically. Second, China has a vast land with different and complex energy structures, industrial structures and regional development status. The policy and regulatory guidance on green finance are conducive to forming a consensus on green development and unifying the institutional standards. ${ }^{59}$ Nevertheless, it is noteworthy that this does not mean that the 'invisible hand' of the government replaces the invisible hand of the market in resource allocation. Instead, government policies help to construct the basic framework of green finance and leverage on tax incentives, financial subsidies and financial policies to support the development of green industries.

Following the policy goals of building the ecological civilization, achieving a green economy as one of the five major development concepts in the 13th 5-year plan, and vigorously encouraging green and low-carbon development, China has rapidly started the construction of a green financial system. ${ }^{60}$ So far, the policy

\footnotetext{
$\overline{53 \text { CBI (2017), p 26, Appendix } 2 .}$

54 Ibid.

55 Ibid.

56 Yeung (2021).

57 Ba et al. (2019).

58 Mai and Xu (2015) and Ba et al. (2018).

59 See Table 1 below for more details.

60 Ibid.
} 


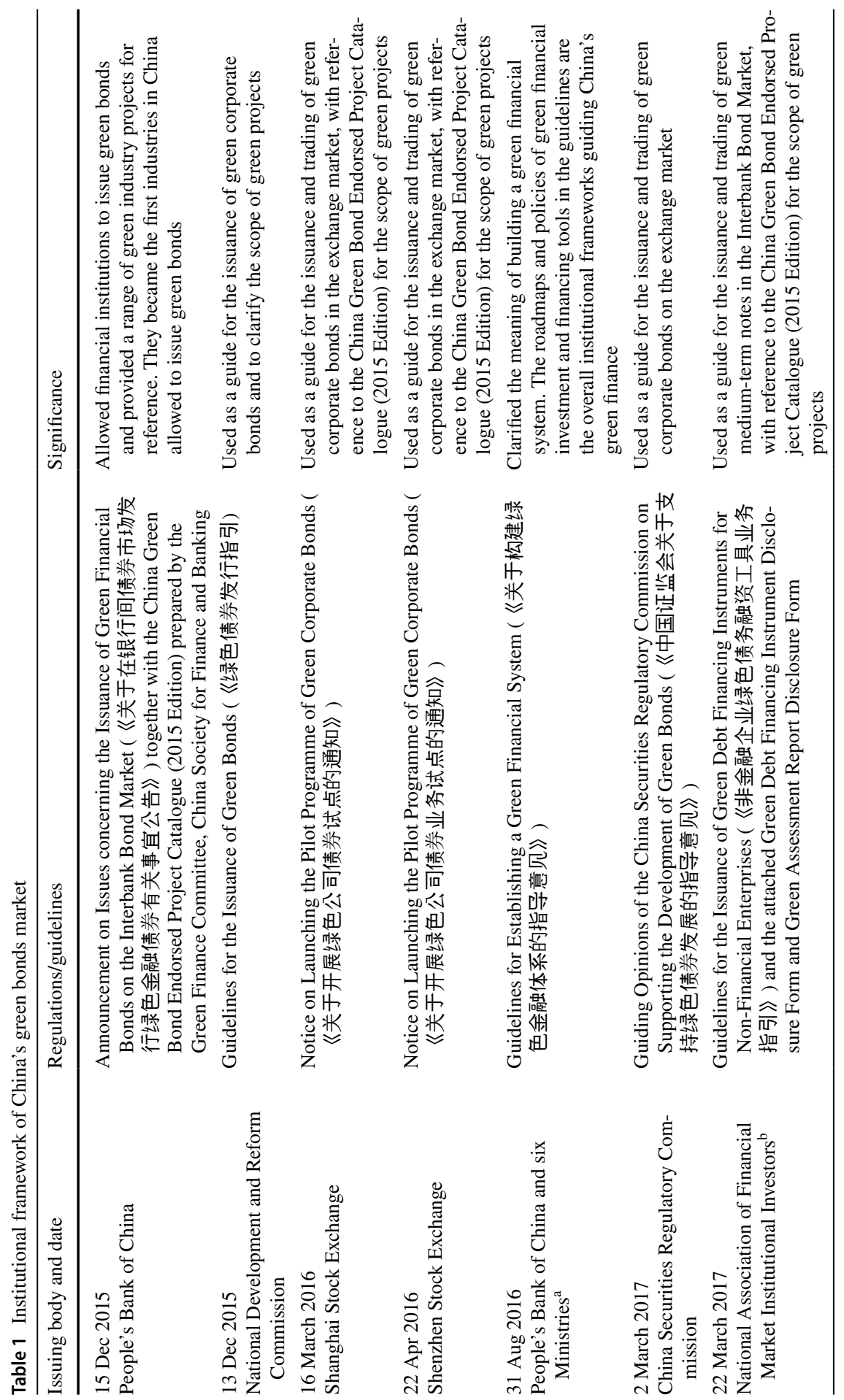




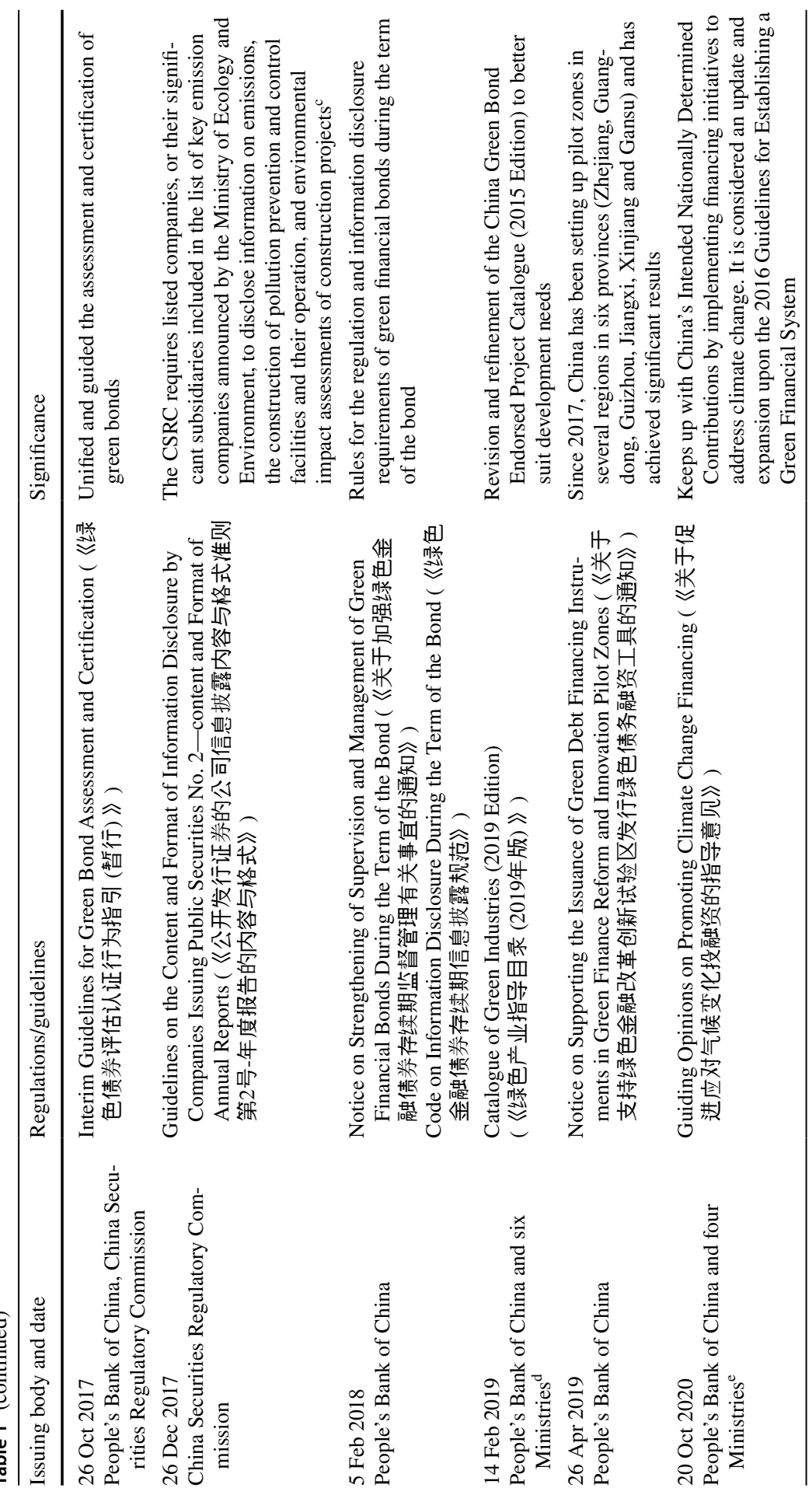




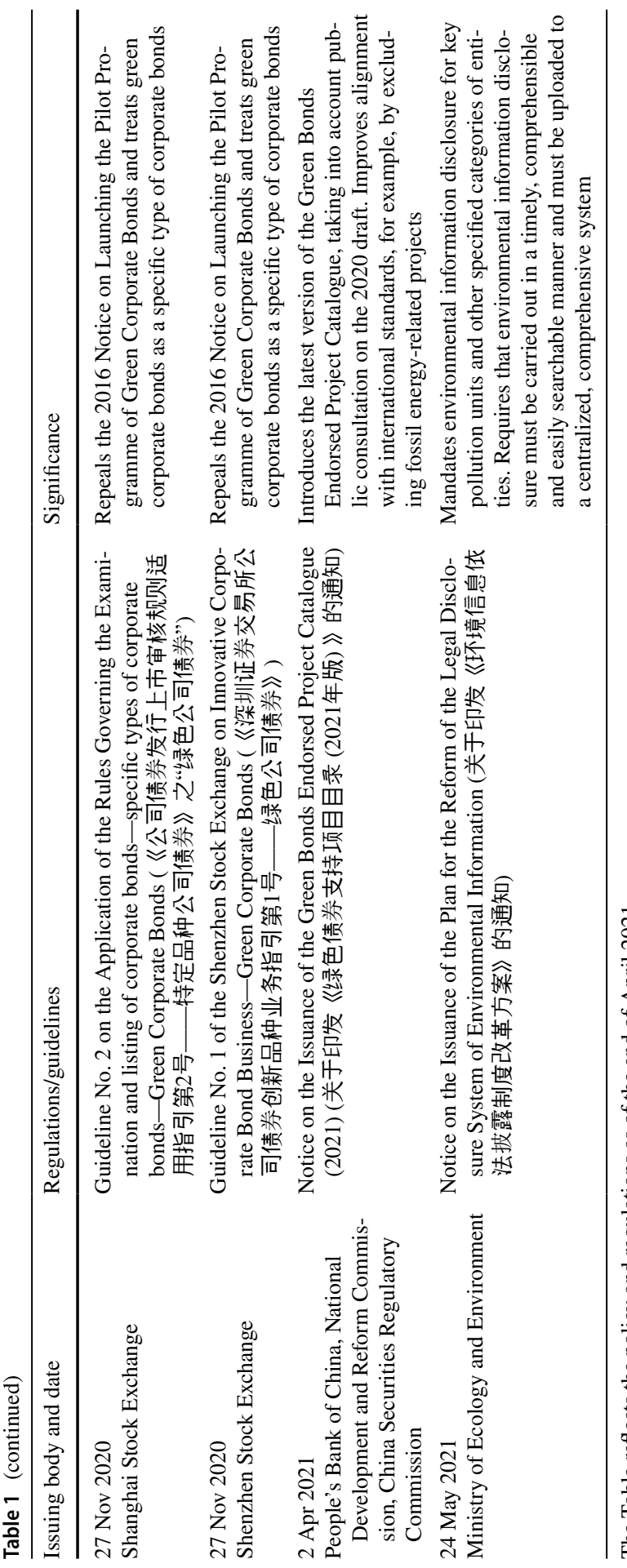

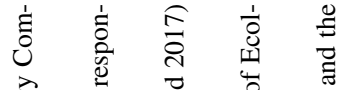

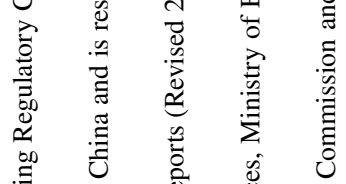

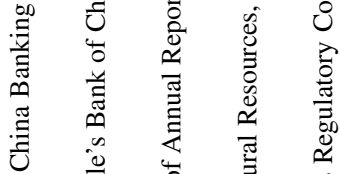

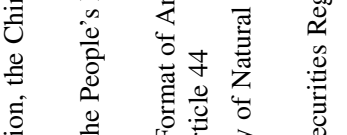

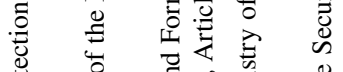

ป

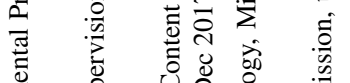

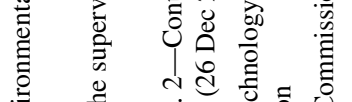

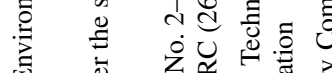

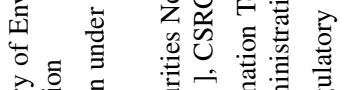

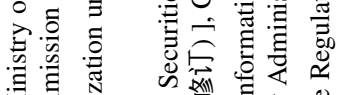

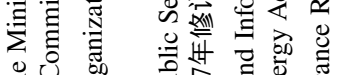

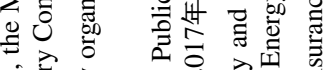

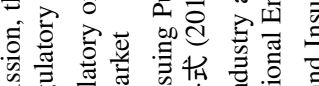

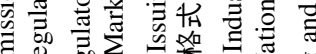

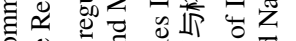

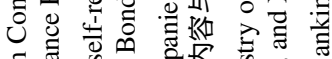

घี

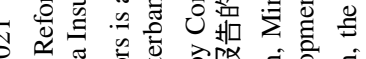

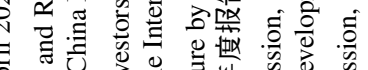

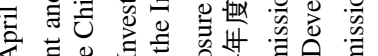

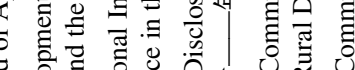

䒕 完豆

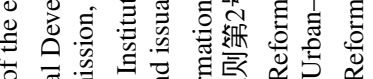

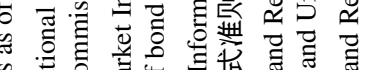

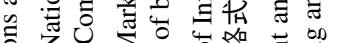

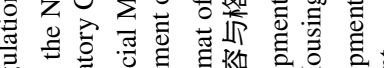

总 \&

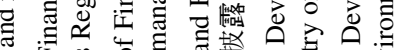

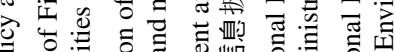

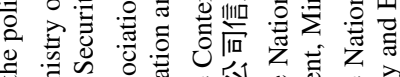

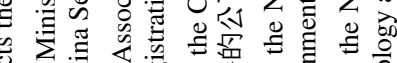

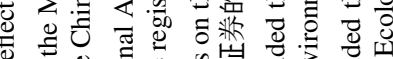

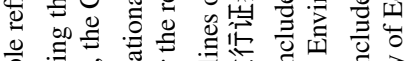

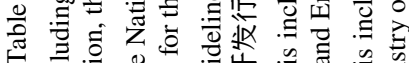

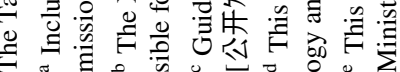


scheme of green development in China has basically covered all green development fields and has formed a relatively comprehensive systematic policy hierarchy. ${ }^{61}$ [See Table 1 above for a summary of major domestic regulations about green finance (including green bonds)]. It should be noted that laws and regulations have different levels of hierarchy in China and the Table mainly presents those at the national level with the highest significance and authority, whereas laws and regulations at the local level will also be canvassed in the following sub-sections.

\subsection{Inter-ministerial Synergy}

The issuance and regulation of green bonds cover a wide range of aspects, including natural resources, environmental protection, energy deployment, economics of people's livelihood, financial management and information sharing. The positive externality of green bonds is difficult for the market alone to internalize within a short period without the help of favorable state financial, fiscal and tax policies. ${ }^{62}$ Inter-ministerial cooperation mechanisms are necessary to facilitate communication, cooperation and coordination among different ministries and regulatory agencies in a nation. This is particularly crucial in the context of China due to the segmentation of the financial regulation system (the so-called 'one bank, two commissions and one committee' system), as well as the co-existence of three corporate credit bonds regimes. ${ }^{63}$

To achieve 'inter-ministerial synergy', different regulators need to jointly discuss and decide on vital matters in the green field and share information on low-carbon development. For example, the PBOC issued the Plan for the Division of Work in the Implementation of the Guiding Opinions on Building a Green Financial System 2017, deciding on the leading ministries and examining the progress of construction article by article, setting a timetable and roadmap for the construction of the green financial system and holding symposiums to ensure implementation. ${ }^{64}$ For another example, the National Leading Group to Address Climate Change was established by the State Council as an important deliberative and coordinating body in the green field. ${ }^{65}$ It studies and formulates major strategies, guidelines and policies for addressing climate change and unifying the active responses to climate change. Such inter-ministerial collaboration is necessary and beneficial in the context of China's facilitating an efficient and fast-paced growth of the green bonds market.

\footnotetext{
${ }^{61}$ China Center for International Economic Exchanges (2013), p 70.

62 Ma (2016), pp 2-3, and Dai and Kidney (2016), p 10.

63 Hong (2010), pp 9-10.

64 Green Finance Dynamics of the Research Bureau of the People's Bank of China: Further Promotion of the Symposium on the 'Division of the Work Plan for the Implementation of the Guidance on Building a Green Financial System [落实〈关于构建绿色金融体系的指导意见〉的分工方案], People's Bank of China (12 Oct 2018), http://www.greenfinance.org.cn/displaynews.php?id=2334 (accessed 31 Nov 2021).

65 See, for example, Xinhua News (2019).
} 


\subsection{Central-Local Unification}

China is a vast country with differences in resource endowments, energy structures and economic development levels among provinces and municipalities in the east, centre and west. Since 2016, China has been taking the central-local unifying approach to set up a systematic framework at the central level, incentivizing local government officials and market players at all levels. ${ }^{66}$ Similarly, central-local unification plays a pivotal role in making sure that targets set by the central government are met or even exceeded at the local level.

Since June 2017, China has selected nine cities in six eastern, central and western provinces to establish green financial reform and innovation pilot zones. ${ }^{67}$ Such pilot zones explore green financial development models with regional characteristics, pilot new green financial regulations and standards, provide green financial services for the green transformation of the regional economy and gain a number of replicable beneficial experiences while making remarkable achievements. ${ }^{68}$ As of the end of 2020, the stock amount of green bonds in the above-mentioned pilot zones was RMB 135.05 billion. ${ }^{69}$

Local governments with more resources and showing greater economic progress should step forward in experimenting with green finance regulations and setting a role model for the other regions to follow. Take Shenzhen for instance: the Shenzhen Special Economic Zone Green Finance Regulations were issued on 5 November 2020 and became effective on 1 March $2021 .{ }^{70}$ The Green Finance Regulations provide the legal basis in terms of standards and procedures, investment evaluations, information disclosure, monitoring and governance, as well as responsibilities and liabilities in relation to green finance. ${ }^{71}$ They are the first green finance regulations in China and provide the legal basis for regulatory actions against misbehaving market participants. $^{72}$

The implementation of the Green Finance Regulations is subject to sufficient market and infrastructure conditions in Shenzhen. Shenzhen has a relatively large share of green bonds. By the end of 2020, the balance of green loans from depository financial institutions in Shenzhen was nearly RMB 350 billion, accounting for $5.1 \%$ of the balance of various loans. ${ }^{73}$ The financial institutions in Shenzhen have

\footnotetext{
${ }^{66}$ People's Bank of China Research Bureau (2019), p 3.

${ }^{67}$ Ibid. For example, the Standing Committee of Shenzhen People's Congress issued the Shenzhen Special Economic Zone Green Finance Regulations in 2020 in order to promote the development of green finance, enhance the ability of green financial services to contribute to the real economy, promote the construction of a sustainable financial centre in Shenzhen, and promote sustainable economic and social development, according to the basic principles of relevant laws and administrative regulations, combined with the actual situation in the Shenzhen Special Economic Zone.

${ }^{68}$ Ibid.

${ }^{69}$ People's Bank of China (2021a).

${ }^{70}$ Shenzhen Special Economic Zone Green Finance Regulations, issued by Shenzhen People's Congress on 5 Nov 2020 and effective from 1 March 2020.

${ }^{71}$ Ibid., Chapters II, IV, V, VII and VIII.

${ }^{72}$ Shenzhen Municipal Financial Regulatory Bureau (2021).

${ }^{73}$ Ibid.
} 
also gradually started systematic sustainability information disclosure, as over half of the sample financial institutions involved in a study by the Green Finance Committee of the Institute of Finance in the Special Economic Zone had begun making public disclosure of sustainability information. ${ }^{74}$ Additionally, due to its rapid economic progress, Shenzhen has the requisite private capital to invest in green bonds and the relevant expertise to monitor the health of the green bonds market and detect malpractices such as green-washing. ${ }^{75}$

The financial institutions in Shenzhen are also well prepared for the implementation of the Green Finance Regulations. ${ }^{76}$ The Industrial Bank, as the first Equator Bank in China, and a pioneer in green finance, has set up an internal governance structure to adapt to the development of green finance and actively participated in the building of the green financial system in Shenzhen. Another example is the Shenzhen branch of the China Development Bank, which also actively supports the Green Finance Regulations and played a major role in the formation of the Green Finance Committee. $^{77}$

As can be seen from the Shenzhen example, some municipalities are better prepared to take more progressive steps in developing the green bonds market due to the relative abundance of resources, expertise and environmental education. They should therefore implement relevant laws and regulations in advance of nationwide implementations. Such pilot projects can lend valuable experience and learning points for national roll-out at a later stage.

\subsection{Integrating Sustainability Goals with Official Performance Evaluation}

In order to provide a powerful incentive for local officials to faithfully and efficiently implement national policies on green finance, the Chinese government tied sustainability goals to the performance evaluation and promotion process for officials. Since 2005, China has been actively promoting the assessment of the environmental performance of leading officials in their respective jurisdictions to strengthen environmental protection measures by targeting the governmental organization. ${ }^{78}$ Four indicators of environmental protection, namely enforcement of environmental protection laws, pollution emission intensity, change in environmental quality, and public satisfaction, were included in the assessment system for local government officials of all levels. ${ }^{79}$ This fundamentally changes the phenomenon of local officials unilaterally pursuing GDP growth without paying attention to environmental indicators and links the problem of the deteriorating environmental quality directly to the power of officials. Among the four new indicators, pollution emission intensity is a qualitative index to comprehensively measure pollutant emissions. Changes in environmental

\footnotetext{
74 Ibid.

75 Ibid.

76 Xinhua News (2021a).

77 Ibid.

78 Sina News (2005).

79 Ibid.
} 
quality are measured by regular environmental tests conducted by local environmental monitoring agencies to reflect changes in environmental quality at different times. The other two indicators-enforcement of environmental laws and public satisfaction-are relatively difficult to quantify. Environmental law enforcements are determined by reviewing enforcement records to determine whether the departments have complied with the environmental laws. Public satisfaction is determined by the number of public complaints about environmental problems.

Additionally, on 6 December 2013, the Organization Department of the CPC Central Committee issued the Notice on Improving the Performance Appraisal of Local Party and Government Bodies and Leading Officials. ${ }^{80}$ This includes more comprehensive content regarding the local party leadership's and government officials' target performances, as well as a change in the format of the review and inspection of their performance. In addition to economic indicators, such performance indicators now include political, cultural, social and ecological progress and other aspects that showcase 'actual effectiveness' ${ }^{81}$ In 2016, the General Office of the CPC Central Committee and the General Office of the State Council issued the Ecological Progress Target Evaluation and Assessment Methods. ${ }^{82}$ Subsequently, the National Development and Reform Commission, the National Bureau of Statistics, the Ministry of Environmental Protection and the Organization Department of the CPC Central Committee formulated the Green Development Index System and the Ecological Progress Assessment System as the basis for the evaluation and assessment of ecological progress. ${ }^{83}$ On 24 October 2020, the Organization Department of the CPC Central Committee issued a circular on improving performance appraisals to promote high-quality development. ${ }^{84}$ It stipulates that the "comprehensive performance evaluation of high-quality development' is an important part of the performance evaluation of local party units and government bodies, and of leading officials of all levels. It also provided that, in response to the demand for innovative, coordinated, green, open and shared development, key indicators should be set precisely and assessments should be conducted on a tiered and classified basis.

Local governments have also cooperated with the central government's officials assessment reform. For example, in September 2017, Jiangsu Province introduced the Implementation Measures for the Ecological Progress Target Evaluation and Assessment in Jiangsu Province, the Jiangsu Province Green Development Index System and the Jiangsu Province Ecological Progress Assessment System. ${ }^{85}$ These policies require that the party committee and government of each district and city

\footnotetext{
${ }^{80}$ Notice on Improving the Performance Appraisal of Local Party and Government Bodies and Leading Officials, issued by the Organization Department of the CPC Central Committee (6 Dec 2013).

81 Ibid., point 1.

82 Goals Evaluation and Assessment Methods for the Construction of Ecological Civilization [生态文明 建设目标评价考核办法], State Council (2 Dec 2016).

83 Xinhua News (2017).

${ }^{84}$ Notice of the Organization Department of the Central Committee of the CPC on Improving the Performance Assessment for Promoting High-quality Development [中共中央组织部关于改进推动高质量 发展的政绩考核的通知], Organization Department, Central Committee of CPC (24 Dec 2020).

85 People.cn (2017).
} 
will implement the '1-year evaluation and 5-year assessment' mechanism for ecological progress targets. The assessment of whether targets are achieved is based on a score out of 100 marks, and categorized into four grades, namely excellent, good, qualified and unqualified. The leading appraisal department collates the scores of each district or city and their relevant situations, proposes the appraisal grading, and handles the appraisal results. This is combined with the formulation of assessment reports based on the audited results of the inspection of outgoing leading officials' natural resources and assets usage, environmental protection responsibilities and environmental protection. The assessment reports are published to the public after being examined and approved by the Jiangsu Provincial Party Committee and the Provincial Government.

The assessment results serve as an important basis for the comprehensive assessment and evaluation of the party and government bodies and leading officials in each district or city, as well as the reward, punishment, appointment and removal of officials. ${ }^{86}$ The Jiangsu Province Green Development Index System is mainly used to measure the dynamic progress of the local ecological progress each year, covering seven primary indicators, i.e. resource utilization, environmental management, environmental quality, ecological protection, growth quality, green life and public satisfaction, as well as 56 secondary indicators. ${ }^{87}$ The Jiangsu Province Ecological Progress Assessment System includes 24 indicators in 5 aspects, i.e., resource utilization, ecological and environmental protection, annual evaluation results, public satisfaction, and ecological environmental events, among which 16 indicators are resource and environmental constraint indicators. The assessment grade of the region is determined unqualified if three or more of such constraint indicators are not satisfied. Meanwhile, 'adverse ecological and environmental events' result in score deductions. Each occurrence of a major environmental emergency, a major source of environmental pollution that causes severe social impact, or an incident that causes serious ecological damage results in a deduction of 5 points, up to a maximum deduction of 20 points. Both systems emphasize public participation, not only allowing people to have a say in the evaluation and assessment process, but also striving to harmonize the assessment results with public opinion. Therefore, 'public satisfaction' is an important indicator that is included in the Jiangsu Province Ecological Progress Assessment System, amounting to 10 points.

Similarly, in February 2021, Shenzhen completed the Gross Ecosystem Product (GEP) accounting ' $1+3$ ' system, led by the GEP accounting implementation plan and supported by technical specifications, the statistical reporting system and the automatic accounting platform. ${ }^{88}$ This means that GDP will no longer be the only indicator to measure development, and GEP will become the 'green baton' to lead Shenzhen's future development. In terms of the local standard for GEP accounting, the Shenzhen Administration for Market Regulation issued the Technical Specification for the Gross Ecosystem Product (GEP) Accounting in Shenzhen, which establishes a two-level indicator system for GEP accounting, as well as the technical

\footnotetext{
86 Ibid.

87 Ibid.

${ }^{88}$ Xinhua News (2021b).
} 
parameters and accounting methods for each indicator. ${ }^{89}$ Amongst the indicators, three are primary indicators, namely material products, regulation services and cultural tourism services. There are 16 secondary indicators, including, e.g., agriculture, forestry, animal husbandry and fishery products, climate regulation, water conservation, air purification, tourism and leisure services. Under the GEP accounting statistical reporting system, more than 200 accounting data are divided into 4 categories: ecosystem monitoring, environment and meteorological monitoring, socio-economic activities and pricing, and geographic information. Data sources and filling requirements are comprehensively regulated, involving 18 departments and 48 forms. Lastly, the GEP automatic accounting platform can facilitate online data filling and generate accounting results with one click, which greatly improves the efficiency and accuracy of the accounting.

It can be seen from the preceding analysis that efforts have been made at both the national and municipal level to integrate environmental protection with the performance evaluation of officials. Such moves are applaudable as they provide the appropriate incentive structure for officials to emphasize sustainability and pursue economic progress in a sustainable way.

\subsection{The Role of the Courts}

In the transition towards a low-carbon green economy, it is foreseeable that certain types of legal disputes will increase in number due to adjustment by companies under new regulations and a surge in the number of green investments. Accordingly, courts need to be forward-thinking and prepared to adjudicate such disputes when they arise.

To achieve carbon neutrality by 2060 , related laws, regulations and policies will be gradually introduced and implemented in China. ${ }^{90}$ As a result, a large number of enterprises will face production reduction, shutdown, default on contracts, or even restructuring and bankruptcy as a result of mandatory capacity reduction, being assigned the air pollution control catalogue, or not falling under the Green Industry Guidance Catalogue. Cases involving contractual disputes arising from industrial restructuring in key industries, green credit disputes, green bond disputes, administrative penalties, administrative compulsory measures, among other things, will likely increase. In 2021, the Ministry of Ecology and Environment issued the Management Measures for Carbon Emission Trading, and disputes and controversies will inevitably arise during the trading process. ${ }^{91}$

The Supreme People's Court has already proposed to make good forecasts, publish leading judgments in due course, formulate judicial policies and propose judicial solutions. ${ }^{92}$ This especially applies to cases involving climate change response

\footnotetext{
89 Ibid.

90 See Table 1 above.

91 Notice of the Supreme People's Court on the Issuance of the Type and Statistical Specification of Environmental Resources Cases (for Trial Implementation) [最高人民法院关于印发《环境资源案件 类型与统计规范 (试行) 》的通知], Supreme People's Court (4 Feb 2021), SPC Order No. 9 of [2021].

$92 \mathrm{Xu}$ and $\mathrm{Su}(2020)$.
} 
triggered by the development of renewable energy, reduction of energy consumption, carbon emission transformation, sustainable transportation, construction, etc. It also covers new types of green finance and carbon finance-related cases, with factual scenarios involving the provision of financial services to promote green low-carbon development, industrial transformation, and the application of new energy-saving and environmental protection technologies, equipment and product research.

On 4 August 2017, the Supreme People's Court proposed to explore the possibility of specialized financial trial institutions on the basis of the characteristics of financial disputes and cases. ${ }^{93}$ In his speech at the World Judicial Conference on the Environment that took place at Kunming, Yunnan, on 26 May 2021, Zhou Qiang, the Chief Justice of the SPC, reiterated China's resolve to strengthen the environmental rule of law. ${ }^{94} \mathrm{He}$ emphasized three important aspects of the SPC's endeavor, namely specialized courts and tribunals for the adjudication of environment-related disputes, public participation in and monitoring of environmental issues, and the use of technology in dispute resolutions. ${ }^{95}$

Courts have a role to play in contributing towards sustainability for a few reasons. ${ }^{96}$ For instance, green finance courts can play a part in reducing financial risks and in promoting the sustainable development of financial institutions by strengthening the risk control norms of financial institutions in anticipation of potential lawsuits. Moreover, green finance courts assume their conventional role of deterrence. ${ }^{97}$ Judicial decisions and punishments not only increase the cost of non-compliance and illegal activities that damage the environment, but also guard against systemic risk in the green finance system. ${ }^{98}$ The use of a blacklist of institutions with records of litigation or dishonest behavior in tapping into green bonds (e.g., green-washing or fraudulent disclosure) discourages short-termism and prevents markets for lemons. ${ }^{99}$ Furthermore, green finance courts and public prosecutors could actively prosecute companies that violated environmental protection laws and therefore send a strong signal to the market of the importance and seriousness of environmental protection. In this respect, much more can be undertaken and gradually implemented as such green finance courts are currently limited in number and still at their infancy stage.

\section{Special Characteristics of the Green Bonds Market in China and Recent Trends Towards International Convergence}

Currently, China's green bonds market has a number of characteristics that differ from other major market and international standards. Most importantly, these include the profile of major issuers, requirements on the use of proceeds, sustainability

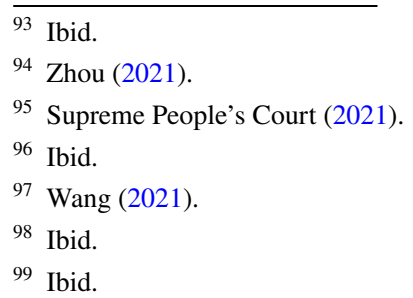


information disclosure and credit ratings. Some of these features that create difficulties and cause hindrance for the long-term growth of China's green bonds market are examined closely in this Section. But before delving into the specific features, the authors would like to acknowledge a general trend towards greater consistency, standardization and international convergence in China's green bonds standard.

Inconsistency and lack of standardization in green projects potentially hinder the evaluation and comparison of green projects. This risk is not unique to the Chinese market. As alluded to earlier, there are three sets of independent green bonds regulatory and supervision systems in China. ${ }^{100}$ Previously, there used to be a lack of unified standards in green project classifications and no common set of indicators such as carbon emission. As a result, investors found it hard to effectively assess and compare green projects. The issuers of green bonds could also take undue advantage in terms of green-washing, aggravating the moral hazard problem in this context.

In recent years, the international green bond standards have undergone a widespread update. The ICMA, which first proposed the four principles of green bonds, updated the contents of the Green Bond Principles in June 2018 and of the Green Bond Impact Reporting in December 2020. ${ }^{101}$ Additionally, the ICMA's Handbook of Harmonized Framework for Impact Reporting refines and explains the disclosure methods and indicators for major categories of green projects and provides guidelines and templates for issuers to prepare impact reports, so as to further enhance the transparency and comparability of information on green bonds. ${ }^{102}$ The CBI, the main designer of climate bond standards, released version 3.0 of the Climate Bonds Standard in December 2019. This new version strengthens public disclosure requirements and timeliness for green bonds, advocates for more pre-issuance disclosure and further clarifies the certification requirements and use. ${ }^{103}$

Since 2018, the EU has accelerated the pace of development of sustainable financing. The EU Green Bond Standard released in March 2019 shares similar features with the Green Bond Principles and the Climate Bonds Standard. ${ }^{104}$ Additionally, the Report on EU Green Bond Standard issued in March 2020 specified that green economic activities should contribute to one of six environmental objectives, ${ }^{105}$ including climate change mitigation, climate change adaptation, and adhering to the requirement of 'doing no significant harm' to any of the other environmental objectives. ${ }^{106}$ These new criteria are expected to become the next international benchmarks for green bonds.

\footnotetext{
100 See text accompanying note 37 supra.

101 See supra note 1 for the four principles.

102 International Capital Market Association (2021).

103 See CBI (2019).

104 EU Technical Expert Group on Sustainable Finance (2019a), p 13, Table 1.

105 EU Technical Expert Group on Sustainable Finance (2019b), p 19. It also includes the following four major goals: sustainable use and protection of water and marine resources, transition to a circular economy, waste prevention and recycling, and pollution prevention control and protection of healthy ecosystems, p 16.

106 Lu (2020), pp 77-78. See also Ma (2021).
} 
In this light, in recent years, China has begun to harmonize its regulations and standards with the new international standards. Some progress has already been made. The Green Bonds Standards Committee was set up as a new self-regulatory authority and coordination mechanism for green bonds in December 2017. ${ }^{107}$ In July 2020, the People's Bank of China, the National Development and Reform Commission and the Securities Regulatory Commission jointly released the China Green Bond Endorsed Project Catalogue (2020 Version) (Draft for Comments) for the first time for public consultation. ${ }^{108}$ The 2020 version of the Catalogue is highly compatible with the Catalogue of Green Industries (2019 Edition) and inherits the basic principles of the China Green Bond Endorsed Project Catalogue (2015 Version). It unifies the domestic green bonds market in terms of the projects and fields endorsed, making significant progress for the standardization of green finance. ${ }^{109}$ The 2020 version of the Catalogue also expands the green bonds market by increasing the categories of endorsed green consumption and trade projects and by extending the scope of endorsed projects to areas such as agriculture and ecological protection. ${ }^{110}$ Compared to the original two green project Catalogues, the new version eliminates projects involving the clean use of fossil energy and includes climate-friendly projects, which is an important step forward in the alignment with international standards. ${ }^{111}$ Most recently, the Green Bond Endorsed Project Catalogue (2021 Version) was introduced in April 2021, having taken into account public opinions in response to the 2020 draft. $^{112}$

Furthermore, China actively participates in bilateral and multilateral international exchange platforms, such as the International Platform for Sustainable Finance (IPSF) which it established together with the European Commission. ${ }^{113}$ China is also taking steps to establish a working group on green classification terminologies, and is conducting a study, organized by the People's Bank of China and its European counterparts, in exploration of the similarities and differences between the green

\footnotetext{
107 Whiley (2018).

108 Notice on the Public Consultation and the Issuance of the Green Bonds Endorsed Projects Catalogue (2020) (Draft for Public Consultation) [《绿色债券支持项目目录 (2020年版)》(征求意见稿)], issued by the PBOC, CSRC and NDRC (8 July 2020). See further Response to the Public Consultation on the Announcement of the Issuance of Green Bonds Endorsed Projects Catalogue (2020) (Draft for Public Consultation) [关于《绿色债券支持项目目录 (2020年版) (征求意见稿)》公开征求意见的反馈], issued by the PBOC, CSRC and NDRC (27 Apr 2021).

109 Ma (2020).

110 Ibid.

111 Taking into account China's economic and social development, its industry development and characteristics of its biodiversity and ecological environment, the new version of the catalogue retains many characteristics of a developing country. This is so as to provide a reference path for the development of green finance in developing countries along the 'Belt and Road' initiative. See Ma et al. (2020), p 16.

112 Notice on the Issuance of the Green Bonds Endorsed Project Catalogue (2021) [关于印发《绿色 债券支持项目目录 (2021年版)》的通知], issued by the PBOC, CSRC and NDRC on 2 Apr 2021 and effective from 1 July 2021, PBOC Order No. 96 of [2021]; Response to the Public Consultation on the Announcement of the Issuance of the Green Bonds Endorsed Projects Catalogue (2020) (Draft for Public Consultation) [关于 《绿色债券支持项目目录 (2020年版) (征求意见稿)》公开征求意见的反馈], issued by the PBOC, CSRC and NDRC (27 Apr 2021).
}

113 SWITCH Asia (2019). 
financing standards in China and Europe with the intent of harmonizing their standards in 2021. ${ }^{114}$ Importantly, China is working with the EU to push for greater convergence of taxonomies of green finance and investments. On 21 March 2021, the People's Bank of China announced that China was working with the EU to adopt a China-EU Shared Classification Catalogue for Green Finance. ${ }^{115}$ The PBOC's announcement followed related milestones in the EU, namely the debut of the EU Sustainable Finance Disclosure Regulation and the EU Taxonomy Climate Delegated Act in March to April 2021. ${ }^{116}$ To push this harmonization even further, the adoption and incorporation of a globally recognized green taxonomy, reporting and disclosure regime was discussed at the G20 Summit in Rome in October 2021. ${ }^{117}$ All these efforts culminated in the Common Ground Taxonomy-Climate Change Mitigation Instruction Report, issued by the IPSF Taxonomy Working Group on 4 November 2021. ${ }^{118}$

At the PBOC-IMF High-Level Seminar on Green Finance and Climate Policy held on 15 April 2021, Yi Gang, the Governor of the PBOC, noted that, to achieve the '30/60' goal, China will need to invest RMB 2.2 trillion per year to reduce carbon emissions by 2030, and RMB 3.9 trillion per year from 2030 to 2060, and private capital participation is indispensable in this process. ${ }^{119}$ To encourage the participation of private capital, he noted the importance of information disclosure and the provision of policy incentives. In terms of information disclosure, the PBOC plans to set up a mandatory disclosure regime with uniform standards, and to promote greater information sharing between financial institutions and companies. ${ }^{120}$ The importance of harmonization with international green taxonomy standards is again emphasized. Regarding policy incentives, the PBOC plans to launch a set of facilitative mechanisms to provide low-cost funds for carbon emission reduction, and to strengthen its support of green finance through measures such as commercial credit ratings, deposit insurance rates, and open market operations. ${ }^{121}$

China has actively sought other venues of international cooperation on green finance. For instance, China took the opportunity of its G20 presidency in 2016 to introduce green finance into G20 motions for the first time, leading the creation of the G20 Green Finance Study Group and promoting the formation of a global consensus on green finance. ${ }^{122}$ To date, this mechanism has exerted significant influence. In December 2017, China co-launched the Green Finance Network (NGFS) of central banks and regulators, focusing on the impact of climate change on macrofinance stability and macroprudential regulation, aiming to strengthen the risk management of the financial system and to mobilize capital for green and low-carbon

\footnotetext{
$\overline{114}$ People's Bank of China (2021a).

115 Latham and Watkins LLP (2021), Chen Jia (2021).

116 Doyle (2021).

117 Latham and Watkins LLP (2021).

${ }^{118}$ IPSF (International Platform on Sustainable Finance) Taxonomy Working Group (2021).

119 People's Bank of China (2021b).

${ }^{120}$ Ibid.

${ }^{121}$ Ibid.

${ }^{122}$ International Institute for Sustainable Development (2016).
} 
investments. ${ }^{123}$ At the end of 2018, the Green Finance Professional Committee of the Chinese Society of Finance and the City of London jointly launched the Green Investment Principles (GIP) which introduced green and sustainable development into the investment and financing activities of the Belt and Road, and 39 Chinese and foreign financial institutions have signed the GIP. ${ }^{124}$ In addition, China has carried out various forms of international dialogues and cross-border efforts on green finance through bilateral platforms, such as the Sino-British Economic and Financial Dialogue and the Sino-French High-Level Economic and Financial Dialogue. ${ }^{125}$

As can be seen from the preceding analysis, the Chinese government has gained some momentum in terms of the unification of its domestic green bond standards and the convergence with international standards. It is of crucial importance that this endeavour be carried out in a thorough and consistent manner, paying special attention to the different aspects highlighted in the following sub-sections, including, most importantly, requirements regarding the use of proceeds, sustainability information disclosure and credit ratings. Following the international standards would help to resolve some of the hindrance created by the above-mentioned unique features of China's green bonds market. China's green bonds market stands to benefit from this convergence process as not only domestic but also overseas private capital would flow into the market when investors become more confident of its standardization and governance. Where applicable, recent reforms and recommended changes are included for a holistic analysis.

\subsection{Profile of Major Issuers}

In contrast with other markets where private issuers play a significant role, the major issuers of green bonds in China have been state-related entities so far. While there has been a change in the profile of major issuers of green bonds over the years, the main groups of issuers remain state-dominated or state-associated. Since 2016, policy banks and large commercial banks have been the main issuers of green financial bonds, with increased participation from small and medium-sized financial institutions (e.g., urban commercial banks) in recent years. ${ }^{126}$ Non-financial enterprises became the largest group of issuers of green bonds in $2019 .{ }^{127}$ Nevertheless, these non-financial enterprises still comprise mostly state-owned enterprises and a relatively smaller number of private enterprises. This situation is less than optimal as it leaves untapped the potential of private enterprises in China's green bonds market. Further recommendations on how the government can adjust the incentives and

\footnotetext{
123 See, for example, Yi (2020). The initial institutions include the People's Bank of China, the Central Bank of the Netherlands, the Bank of France, the Bank of England, the German Central Bank, the Swedish Monetary Authority, the Monetary Authority of Singapore, and the Central Bank of Mexico, and now the membership has expanded to 83 institutions.

124 Green Belt and Road Initiative Centre (2021).

125 UK Treasury (2019) and CGTN (2020).

126 China Green Bonds and Credits (2018).

127 CBI \& CCDC Research (2020), p 4.
} 
constraints in the market to encourage participation by private enterprises can be found in Section 4 below.

\subsection{Use of Proceeds}

The Chinese requirements on the use of proceeds for green bonds also differ from international standards. The rule is that $100 \%$ of green financial bonds and mediumterm notes, at least $70 \%$ of green corporate bonds and $50 \%$ of green enterprise bonds are to be invested in green projects. ${ }^{128}$ In comparison, this threshold can be as high as $95 \%$ in the international rules. ${ }^{129}$ The low threshold applied in China causes concerns about misuse of proceeds and green-washing. In practice, a portion of the capital is used for repaying debts, supplementing operation expenses, and other non-green purposes. For this reason, the Green Bonds Database managed by the CBI excluded USD 6.6 billion (RMB 46 billion) worth of purported green bonds in 2019. ${ }^{130}$ While allowing the use of a large proportion of green bonds financing for peripheral purposes helps to meet the needs of green bond issuers and boosts the supply and scale of green bonds, it undermines the intended effect of green investment, weakening investor confidence, the appeal of green bonds and their valuations.

Another related concern is the major area of green bonds investment. In practice, the funds raised are mainly invested in clean transportation and clean energy projects, with a relatively smaller percentage of raised funds invested in ecosystembased adaptation projects or pollution prevention and energy efficiency projects. ${ }^{131}$ As such, the focus is on the reduction of energy consumption per unit, the elimination of environmental pollution and the curtailment of environmental damage, and on directing the limited policy supports and grants to transforming the industries that have the greatest impact on the environment and display the highest urgency in promoting green development. ${ }^{132}$ As mentioned earlier, it is only until recently that fossil-based green energy projects have been excluded from the scope of green bonds; unlike international green standards, such projects used to qualify for green bonds in China. ${ }^{133}$ The problem with this old arrangement was that although it fit the needs of China in the industrialization process, it limited the potential growth of green bonds, the alignment of the Chinese green standards with international ones, and the utilization of foreign funds.

The authors argue that, similar to the exclusion of fossil-based green energy projects, China can put in greater efforts aimed at the alignment of scope. For instance,

\footnotetext{
128 Climate Policy Initiative (2020a), p 5, Table 2.

129 CBI \& CCDC Research (2020), p 13.

130 CBI and SynTao Green Finance (2020), p 18.

131 CBI \& CCDC Research (2020), p 9.

132 Lu (2020), p 78.

133 Xinhua News (2021c). This news article cited the Notice on the Issuance of the Green Bonds Endorsed Project Catalogue (2021) [关于印发《绿色债券支持项目目录 (2021年版) 》的通知], issued by the PBOC, CSRC and NDRC on 2 Apr 2021 and effective from 1 July 2021, PBOC Order No. 96 of [2021]. See also $\mathrm{Ng}$ (2021).
} 
China currently places emphasis on the new energy vehicle industry ${ }^{134}$ while the international standards take a cautious approach in this sector. ${ }^{135}$ Similarly, China does not set carbon emission targets for its green projects ${ }^{136}$ whereas the international standards exclude all projects related to fossil energy sources without carbon capture mechanisms. ${ }^{137}$ Alignment of these areas would help to place China on the same track as other major global players. In this regard, China's guiding philosophy is expected to shift more towards climate change mitigation and adaptation, similar to international standards such as the EU Green Bond Standard. ${ }^{138}$

\subsection{Sustainability Information Disclosure}

In China, sustainability information disclosure is required only to a limited extent. Except for listed companies and a few other specified categories, bond issuers need not disclose information regarding the use of funds or the performance of green projects. ${ }^{139}$ Any information disclosed is mostly descriptive and not quantitative. ${ }^{140}$ The frequency, however, is significant. Chinese banks are required to provide quarterly reports on how the green bonds are used, while corporate issuers must provide annual or semi-annual reports, which is more frequent than stipulated by international standards, which require annual reporting. ${ }^{141}$ In contrast, a number of international green bond standards require bond issuers to disclose reports on the use of funds and information on environmental benefits. ${ }^{142}$ They also recommend that issuers use qualitative performance indicators and/or quantitative performance indicators to measure the environmental impact of projects. ${ }^{143}$

It is recommended that the disclosure of environmental information on green bonds should be mandated alongside the provision of a standardized format for disclosure and the quantification of environmental indicators. This provides

\footnotetext{
134 Yin (2020), p 66.

135 Ibid.

136 Guo (2021), pp 45-46.

137 Ibid.

138 See supra note 104.

139 China Central Depository and Clearing Co., Ltd. (2018), p 31. The specified categories include 'key emission units; enterprises subject to compulsory clean production audit obligations; listed companies, or debt-issuing companies subject to criminal liability or significant administrative penalties due to ecological and environmental violations; and other enterprises as required by laws and regulations', see Notice on the Reform Programme for the Environmental Information Disclosure System [关于印发《环 境信息依法披露制度改革方案》的通知], Ministry of Ecology and Environment (24 May 2021), Ministry of Ecology and Environment Order No. 43 of [2021], Article 2(1) (1).

According to the latest rules, issuers are required to disclose information concerning the intended usage of funds raised from green bonds issuance. See SSE Corporate Bond Issuance and Listing Rules Application Guideline No. 2-Corporate Bonds of Specific Types [上海证券交易所公司债券发行上市审核 规则适用指引第2号一特定品种公司债券], Shanghai Stock Exchange (27 Nov 2020), Article 4.4.

140 Ibid., China Central Depository and Clearing Co., Ltd. (2018), p 32.

141 Climate Policy Initiative (2020a), p 5, Table 2.

142 Hong (2017), p 128.

143 Ibid.
} 
transparency and sufficient information for domestic and foreign investors to make their investment decisions, thereby enhancing investor confidence and increasing investments in China's green bonds market.

In fact, China has been accelerating the process of mandating the disclosure of green bond information. For example, in addition to green financial bonds and green medium-term notes, the fund usage and actual environmental benefits of which must be disclosed, carbon neutral bonds launched in 2021 on the Interbank Bond Market are also subject to the provision of information on their carbon emission reduction and other environmental benefits. ${ }^{144}$ Meanwhile, the Securities Regulatory Commission has also included environmental protection in the scope of voluntary disclosure by companies listed on the Science and Technology Innovation Board. ${ }^{145}$ Moreover, the People's Bank of China organized and developed a green financial information management system to promote information sharing and enhance regulatory effectiveness. ${ }^{146}$ On 24 May 2021, the Ministry of Ecology and Environment issued the Notice on the Reform Programme for the Environmental Information Disclosure System. ${ }^{147}$ The Reform Programme mandates environmental information disclosure for key pollution units, enterprises subject to clean production auditing obligations, listed companies and bond-issuing enterprises subject to criminal liability or major administrative penalties due to ecological and environmental violations, and other enterprises or institutions as required by laws and regulations. ${ }^{148}$ It further requires that environmental information disclosure must be carried out in a timely, comprehensible and easily searchable manner and must be uploaded to a centralized, comprehensive system. ${ }^{149}$

Additionally, at the international level, the pilot work on climate and environmental information disclosure for Sino-British financial institutions (there are already 13 such pilot institutions) continues to advance. ${ }^{150}$ These 13 Sino-British financial institutions have made environmental information disclosures according to the recommendations of the Task Force on Climate-related Financial Disclosure (TCFD) and the Climate and Environmental Information Disclosure Framework set up by China, with clear results and demonstratable effects. ${ }^{151}$

The green bond disclosure system should identify green bond issuers as the primary party responsible for green bond disclosure. They should be encouraged to disclose the carbon footprint of raised funds in a multi-dimensional and

\footnotetext{
144 National Association of Financial Market Institutional Investors (2021a).

145 SSE Guideline No. 2 on the Application of Self-Regulatory Rules for Listed Companies on the STAR Market - Voluntary Information Disclosure [上海证券交易所科创板上市公司自律监管规则适 用指引第2号一自愿信息披露], Shanghai Stock Exchange (25 Sep 2020), Article 4.14.

146 UN Partnership for Action on Green Economy (2016).

147 Notice on the Reform Programme for the Environmental Information Disclosure System [关于印发 《环境信息依法披露制度改革方案》的通知], Ministry of Ecology and Environment (24 May 2021), Ministry of Ecology and Environment Order No. 43 of [2021].

148 Ibid., Section II (1) (1).

149 Ibid., Section II (1) (4).

150 UNPRI (2019).

151 See Energy Foundation (2020), p 3.
} 
comprehensive manner. Additionally, the system should enable external evaluation agencies to prudently verify the content of such disclosures, ${ }^{152}$ and complement the regulatory authorities in ensuring strict enforcement and accountability in order to fulfill China's green bond environmental information disclosure obligations. While certain efforts have been made in this respect, more extensive reforms are required to deliver optimal impact.

\subsection{Credit Ratings and Environmental Risk Analysis}

Finally, green bond credit ratings in China are generally above $\mathrm{AA}+$, with most receiving AAA ratings. ${ }^{153}$ The bonds are mostly certified by domestic third-party evaluation agencies, with a small portion being certified by overseas agencies. ${ }^{154}$ However, there is also a large proportion of bonds that are unrated, and the proportion of green bonds that are certified is currently not as high as desired. ${ }^{155}$ Furthermore, China's green bond standard does not mandate third-party certification. There is no unified or recognized certification process, ${ }^{156}$ with the process varying from institution to institution. This differs greatly from the international green bond standards, which emphasize the importance of third-party certification, requiring the quantification of environmental benefits as a basic criterion for certification. ${ }^{157}$

It is therefore recommended that more efforts be put into the effective assessment of a project's greenness and the establishment of trustworthy credit-rating agencies. The determination of the green attributes prior to the issuance of green bonds also requires active monitoring of the use of raised funds during their subsequent operation and measurement of the environmental benefits they generate. In September 2020, the NGFS released two important documents, i.e., the Overview of Environmental Risk Analysis by Financial Institutions and the Case Studies of Environmental Risk Analysis Methodologies, calling for a concerted effort to promote the use of environmental risks analysis in the financial industry. ${ }^{158}$ As one of the founders of the NGFS, China should take this opportunity to make full use of the expertise of market institutions to accelerate the construction of a statistical database on environmental benefits, to develop and share environmental risk analysis methods and assessment models, and to complete work on green financial investment analysis tools. As the green bonds market becomes increasingly popular, the government should lead the way by redirecting local government subsidies or concessions for individual green bond issuers into various forms of green funds (e.g., green industry funds, green guarantee funds, green M\&A funds, green guidance funds, green

\footnotetext{
152 China Government Securities Depository Trust and Clearing Co. Ltd. and CECEP Consulting Co. Ltd. (2018), p 113.

153 Ibid.

154 Ibid.

155 Ibid. Non-public issuance of bonds does not need to be rated.

156 Shi (2019), p 93.

157 CBI (2019), Part B and Part D.

158 Network for Greening the Financial System (2020).
} 
development funds, etc.) in order to guide the development of green industries. ${ }^{159}$ In doing so, market participants in China should attempt to align with international developments, such as the NGFS guidelines, as much as possible in order to secure international confidence in their environmental risk assessment methodologies right from the start.

Additionally, in-depth use of financial technology in the field of green bonds will arguably improve the accuracy and automation of the systematic measurement of the environmental performance of green enterprises and projects. ${ }^{160}$ For instance, the use of big data analysis may improve the accuracy and sensitivity of external evaluations based on data such as green bond ratings and certifications and promote information sharing. Other forms of measurement technologies such as earth observations via satellites or drones, and spatial finance can help overcome the difficulty with independent verification of sustainability information disclosure. ${ }^{161}$ China has already begun adopting fintech for green finance in some pilot regions. For example, in Huzhou city, the local government makes use of the internet, big data and other technologies to build a comprehensive green finance service platform to reduce environmental and climate-related information asymmetries and to quickly match green enterprises and projects with financial institutions. ${ }^{162}$

\section{Lessons Learnt and Ways Forward}

After canvassing the unique policies and features in China's green bonds market, this Section identifies several problems arising from the top-down approach taken by the Chinese government as well as from the fact that the green bonds market is still at its emerging stage. Such problems include potential misallocation and waste of resources, resource and manpower constraints on the regulators, and the lack of investor education. Targeted recommendations are made accordingly. The last part of this Section makes the case for the evolving role of the government as the green bonds market matures and the approach shifts from a government-oriented to a more market-oriented one.

\subsection{Adjustment of Incentives and Constraints to Ensure Efficient Allocation}

As it stands, there is a disproportionate allocation of capital in China's green bonds market in favor of state-owned enterprises (SOEs). This means that private companies find it harder to secure financing through green bonds and accordingly have a small share in the green bonds market. In 2019, while the number of times that green bonds had been issued by private enterprises had increased to 11, an $83.33 \%$ increase compared to 2018, the actual amount of green bonds issued by private

\footnotetext{
159 An et al. (2018), pp 76-78.

160 Yin (2020), p 67; see also Avgouleas (2021).

161 Avgouleas (2021), pp 68-72.

162 Shanghai Branch of the State Administration of Foreign Exchange (2020).
} 
enterprises (RMB 5 billion, comprising $2 \%$ of the market) was still far lower than that issued by SOEs (RMB 194.937 billion, comprising $79.90 \%$ of the market). ${ }^{163}$ This is still the prevailing situation as at the date of this paper.

As a result, private enterprises that lack a government background or government connections, or have a low credit rating, tend to find it hard to secure a favorable interest rate even though they might have good-quality green projects with significant environmental impact. The lack of participation by private enterprises is undesirable in the long term as it stifles competition, limits the long-term potential of the market and creates potential concerns about the waste of resources or unaccountability of SOEs.

Chinese local policies primarily focus on green projects with high credit ratings, a large scale and relatively mature technology. ${ }^{164}$ However, a number of projects with vast potential in promoting green low-carbon growth may not receive funding because they did not fulfill the local requirements. The issuers of green bonds that are backed by government support enjoy several advantages. ${ }^{165}$ They get quicker approval for issuance from regulatory authorities. They can also use a higher proportion of the capital raised for purposes other than supporting their green projects, as explained above. As some of the companies controlled by local governments find it hard to issue ordinary corporate bonds, they may switch to issuing green bonds for financing. ${ }^{166}$ At the same time, companies in industries heavily regulated by macroeconomic policies may also tend to raise funds by issuing green bonds or even seek undue advantages from the green bond standards yet to be standardized, adding more risks to the system. ${ }^{167}$

On top of inefficient allocation of resources, corruption, fraud and green-washing are potential vices hidden in a top-down approach. As mentioned previously, sustainability information is still a weak link in China's green bonds market. ${ }^{168}$ Because the quality of information disclosure cannot be adequately determined, problems such as fraudulent disclosure and green-washing tend to be present. ${ }^{169}$ In addition, local officials may be influenced by bribery and nepotism to provide green bondsrelated subsidies and grants in an unfair manner, although it should be noted that corruption by officials in China has been strongly subdued in recent years. ${ }^{170}$ Rent seeking is also an area where companies issuing green bonds may accrue undue advantages and benefits by selecting a more favorable regulatory environment, ${ }^{171}$ and such regulatory arbitrage is particularly likely in China, where there used to be different sets of standards governing green bonds. ${ }^{172}$ In this regard, it should be

\footnotetext{
${ }^{163}$ United Equator Bonds Research Institute (2020).

${ }^{164}$ Climate Bonds Initiative and SynTao Green Finance (2020), p 18.

165 Ibid.

166 Ba et al. (2019), p 102.

167 Xiao and Yan (2018), p 85.

168 See Section 3.3 above.

169 See, for example, Harlan (2019).

${ }^{170}$ See, for example, Ting (2020).

171 Park (2018), p 31.

${ }^{172}$ See Climate Policy Initiative (2020a), p 5, Table 2.
} 
noted that the standardization has significantly improved after the PBOC, NDRC and CSRC jointly issued the Green Bonds Endorsed Project Catalogue (2021). ${ }^{173}$

These issues could be aggravated by the resource and manpower constraints of regulators. As regulators face challenges in allocating sufficient resources to the regulation of such matters, the risks associated with under-regulation of illegal activities and non-compliance loom large. ${ }^{174}$ Compared to ordinary bonds, green bonds attract positive attention because of their positive impact on the environment. However, it is much more difficult to quantitatively assess the green nature and environmental impact of such projects. ${ }^{175}$ Regulation of green bonds therefore requires greater manpower, resources and money. Suitable monitoring tools and techniques are needed for each industry. ${ }^{176}$ These requirements far exceed the resource and capability constraints faced by conventional financial regulators. This dilemma brings unprecedented challenges for regulators and results in practical problems such as the difficulty to deal with green-washing in a timely manner. All of these complications make it difficult for regulators to perform their role of safeguarding and promoting the healthy development of the green bonds market.

In this regard, on top of the conventional role of regulators, enforcers and courts, ${ }^{177}$ it is important to contemplate the roles of other market players, such as financial institutions and third-party service providers like law firms, auditing firms and credit-rating agencies. Financial institutions can act as checks and balances of the quality of sustainability information disclosure. ${ }^{178}$ Similarly, credit rating agencies should uphold fairness and be held to their task of quality control, and not be unduly influenced by conflicts of interests. ${ }^{179}$ Law firms should also properly advise their clients on the requirements of the laws and regulations and the risks of noncompliance or green-washing. In this sense, regulations and monitoring are a systematic design instead of a one-sided effort.

Accordingly, China should adjust the incentives and constraints of green bond investment and financing, promote the internalization of the positive externalities of green bonds through market-based mechanisms, and design a suitable environment for the development of green bonds by complementing the market's functions with the government's functions. In this regard, as illustrated in Fig. 2 below, the government's role is to provide sufficient incentives to market players and eventually allow market mechanisms to promote the development of the green bonds market. In doing so, it should provide the institutional framework for issuers to issue green bonds in

\footnotetext{
173 See supra note 112.

174 Ba et al. (2019), pp 102-103.

175 Climate Policy Initiative (2020a), p 3.

176 For instance, the SASB framework devised by the Sustainability Accounting Standards Board provides sector-specific standards and guidance for ESG disclosure in 77 industries, Sustainability Accounting Standards Board (2021).

177 See Section 2.6 for a discussion on the role of the courts.

178 Chang et al. (2019).

179 Climate Policy Initiative (2020a), pp 9-10.
} 


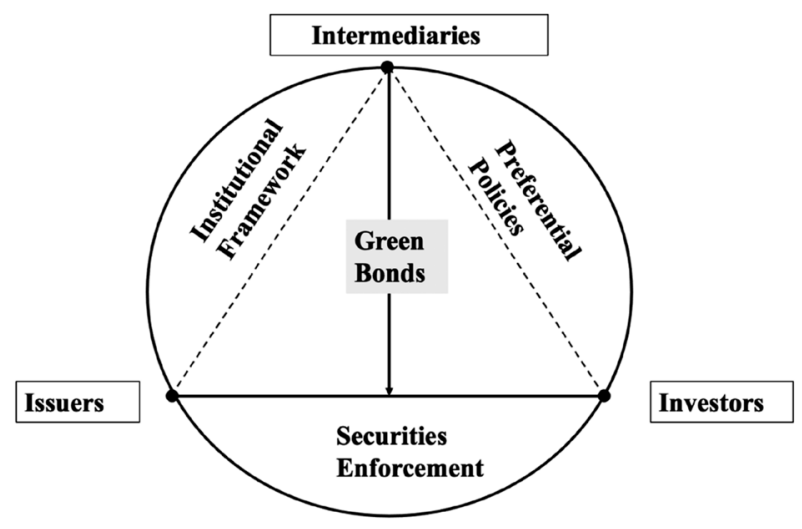

Fig. 2 Government measures to facilitate effective market mechanisms

a conducive regulatory environment, ${ }^{180}$ introduce preferential policies such as tax exemptions and investor education to attract investors to invest in green bonds, and act as an enforcer and a conduit for dispute settlement between issuers and investors to maintain investor confidence in the market.

Government policies can help to construct a favorable institutional framework for green bond issuers in a number of ways. In terms of financing, as of end 2020, the market capitalization of China's green bonds market, which is the world's second largest, only amounted to RMB 813.2 billion. This is much lower than the market size of China's green loans market, which is the world's largest, with a market capitalization of RMB 12 trillion. ${ }^{181}$ As compared to green credit, the financing model of green securities is more direct, and green industries can obtain funds at a lower cost and through a simpler process. ${ }^{182}$ Therefore, it is necessary to increase policy support for green bonds in the future. Achieving a low-carbon green economy requires investment by the masses. In the future, China needs to stimulate private enterprises' interest in joining the green cause and the government should divert more financial concessions and subsidies to such private enterprises as well as to green projects with greater potential environmental benefits. Since private enterprises face certain disadvantages in seeking green financing in the current context, it is recommended that such difficulties should be removed by reforms for the benefit of diversification and healthy competition in the green bonds market.

At the same time, China must guide green bond issuers in investing more raised funds in green projects, release a greater variety of green bonds in accordance with China's economic transition, support the development of not only dark green projects but also medium and light green projects, and develop transition bonds to help

\footnotetext{
180 Such an institutional framework would encompass the key recommendations in this paper, such as greater standardization and consistency of green bonds, and more stringent requirements on information disclosure and use of proceeds.

181 People's Bank of China (2021a).

182 Wang and Ma (2020), p 75.
} 
brown industries transit to becoming green ones. Since green bonds no longer have any advantage in the issuance approval process after the implementation of the new Securities Law as of 1 March 2020, mandating that all corporate bonds comply with the 'registration system', the rules in that law should be adjusted. ${ }^{183}$ A suitable market mechanism and legal liability framework should be formulated for the rational evaluation of green bond prices. These measures, together with market intermediaries that assist green bond issuers with green certification and environmental information disclosure, will raise the costs of environmental damage, hence incentivizing green bond issuers to improve the environmental benefits of green bonds in order to enhance their attractiveness.

\subsection{Improvement of Retail Investor Education}

From the investor's perspective, the lack of investor education means that investors do not have a strong sustainability mindset while the market demands sophisticated retail investors. ${ }^{184}$ In recent years, the negative impact of climate change on socioeconomic conditions has been increasingly felt, particularly amidst COVID-19, and has become an inevitable source of financial risk. ${ }^{185}$ At the same time, the demand for and interest in sustainable investment by retail investors has increased and should be tapped into for further growth of the green bonds market. However, because green bonds carry both the credit risks of ordinary bonds and the environmental risks associated with their environmental goals, investors are required to have relevant knowledge about environmental risks and the methodology to identify, evaluate and manage such risks in their portfolios. ${ }^{186}$

According to statistics, the majority of green bond (medium-term) buyers in 2020 are institutional investors. ${ }^{187}$ There is limited participation by other enterprises and retail investors. Retail investors are still primarily concerned with the financial returns of their investment and not with information disclosure concerning the public welfare goals and the sustainable impact of the use of the funds. ${ }^{188}$ The situation is a far cry from having investors with proper techniques to evaluate and manage environmental risks in their investments. Because of the lack of analytical tools, many investors cannot identify and quantify the credit and market risks arising from environmental factors, and therefore underestimate the risks in unsustainable assets and overestimate the risks in green investment. ${ }^{189}$ As such, the lack of incorporation of concepts and tools for managing environmental risks covered by the Principles

\footnotetext{
183 The Measures for the Administration of the Issuance and Trading of Corporate Bonds (2021 Revision) [公司债券发行与交易管理办法(2021修订)], Order No. 180 of the CSRC [2021] (26 Feb 2021), consolidated the reform of the registration system concerning the public issuance of corporate bonds.

184 See, for example, Daeniken (2020) and Standard Chartered (2020), p 10.

185 Lau (2020).

186 Hong (2017), p 134.

187 National Association of Financial Market Institutional Investors (2021b).

188 Liu (2018), p 110.

189 Ma (2019), p 8.
} 
for Responsible Investment (PRI) ${ }^{190}$ may further limit the sustainable growth of the green bonds market in China.

With regard to further incentivizing investors to invest in green bonds, there is a need to further publicize, and educate people on the importance of a green and lowcarbon circular economy, to encourage investors to use the ESG criteria to screen potential investments, to guide financial resources toward a green, low-carbon circular economy and to enhance investors' preferences for and sensitivity to green attributes. Ideally, green and sustainable development or social welfare should gradually become the main investment objective of investors and the areas that China's domestic markets focus on. ${ }^{191}$ An important pre-condition for attracting sophisticated retail investors to enter the green bonds market is adequate investor protection, demonstrated by enhanced requirements on the use of proceeds, continuous monitoring and certification, and information disclosure, as recommended in this paper.

After investors put their money into the green bonds market, the government's role continues in terms of enforcing green bond issuers' compliance with their obligations and adjudicating disputes between investors and issuers. Much ink has already been spilt about guarding against malpractices, such as fraud and greenwashing, that undermine investor confidence. The role of courts has been canvassed earlier as well. ${ }^{192}$ Ultimately, investors will only stay in the green bonds market when they have enough confidence that the issuers stay true to their commitment to sustainability and any disputes can be resolved in an efficient and fair manner. The government can do much in this respect in terms of regulatory design and boosting judicial expertise in this area.

\subsection{Evolving Role of the Government and Gradual Transition Towards a Market-oriented Model}

On the one hand, China, with a transition economy, has impressed many in pioneering the establishment of a government-led green bonds market that fulfills the goals of green bonds. However, on the other hand, the hidden challenges brought about by China's top-down development model and new pressures arising from the green development at home and abroad render it necessary to recharacterize the government's involvement from that of a government-oriented model with a limited role for the market to a market-oriented model with a limited role for the government. The authors therefore argue that the role of the government should not be a stagnant one where the green bonds market is concerned but requires evolution in response to the level of maturity of the market.

\footnotetext{
190 The Six Principles for Responsible Investment promulgated by the United Nations Environment Programme are as follows: (1) incorporate ESG issues into investment analysis and decision-making processes; (2) be active owners and incorporate ESG issues into our ownership policies and practices; (3) seek appropriate disclosure on ESG issues by the entities in which we invest; (4) promote acceptance and implementation of the Principles within the investment industry; (5) work together to enhance our effectiveness in implementing the Principles; and (6) each report on our activities and progress towards implementing the Principles.

191 Feng et al. (2019), p 502.

192 See Section 2.6 above.
} 
Fig. 3 Evolving role of the government in developing a green bonds market

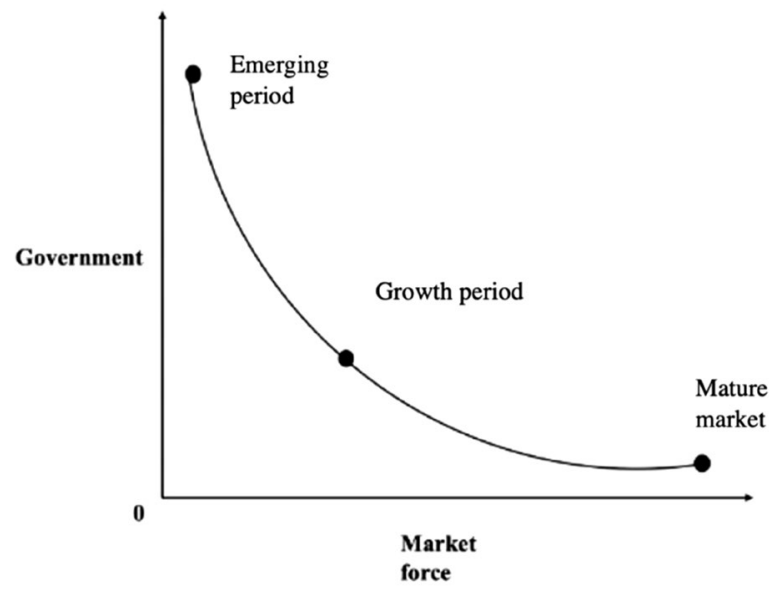

As illustrated in Fig. 3 above, at the emerging stage of the market the government has a greater role to play. Such a role would involve setting up a conducive institutional and regulatory framework, creating preferential policies to attract investors, and providing reliable dispute resolution mechanisms, as explained earlier. Overall, these government interventions are not an end in themselves, but rather a means to reach desirable ends such as diversification, reliability and competence of green bond issuers, sophistication of investors and expertise of the courts. It is not difficult to see that these end goals all drive towards a more mature market where market forces alone can distribute resources in an efficient and environment-friendly way. Similarly, scholars have identified the signs of a mature market as including proper management of information asymmetry, strong investor protection (particularly for minority investors), and continuous monitoring of company directors and managers. ${ }^{193}$

Once there are observable signs of a mature market, the extent of government intervention should be significantly curtailed, letting market forces take the leading role in shaping its development. ${ }^{194}$ At this later stage, the role of government as a limited participant should be reduced to the provision of necessary funding and of efficient dispute resolution mechanisms, and monitoring of the performance of green bond issuers. In fact, overregulation at this stage risks stifling the attractiveness and competitiveness of a market. ${ }^{195}$ By letting market forces take a predominant role, the government will also be mitigating some of the issues related to the top-down approach, such as inefficient allocation of resources. Overall, while at the present stage the government still has a major role to play in terms of putting in place a robust regulatory regime that properly incentivizes different stakeholders to

\footnotetext{
193 See, for example, Black (2001) (although in the context of stock markets the concepts are transferrable).

194 Chen (2014), p 45.

195 Coffee (2007), pp 233-247.
} 
enter the green bonds market, eventually its role is going to diminish to a facilitative monitor in the long run as the market matures.

\section{Conclusion}

China has progressed from a high-energy consumption, high-pollution economic model to a green and low-carbon economic model in its attempt to build an ecological civilization. In the process, China established the world's second largest green bonds market in a short period of time through top-down government-led reforms. This is a significant example of how a country with a transitional economy can build a vibrant green bonds market. The top-down design, unified deployment and efficient implementation of its green bond system and operation mechanisms have empowered China to overcome certain market failures and thereby shorten the natural evolutionary process of the market. This highlights the government's positive role as the institutional force that mandates change. However, despite the initial successes of its green bonds market, China also faced challenges brought about by its government-led reform model that varied between regions and eras. Additionally, China also realized the importance of allowing the market to work hand-in-hand with the government, the importance of giving effect to market mechanisms for resource allocation and the importance of establishing efficient incentive and constraint mechanisms for the market.

In response to the new changes in international green standards and the need to fulfill its '30/60 goal', China must reform and improve on the mechanism and institutional framework of its green bonds market with the aim of unifying its domestic practices and aligning them with international standards. It should further strengthen sustainability information disclosure requirements and cultivate a group of sophisticated retail investors. The role of courts as a bridge between black-letter laws and actual stakeholders such as issuers and investors should be enhanced as well. In implementing these measures, the government needs to be guided by the ultimate goal of constructing an efficient and independent green bonds market driven by market forces with an appropriate institutional design. All these policy reforms will eventually allow the market to further develop and to more effectively promote the making of a green, low-carbon circular economy so as to realize the vision of building a better home on earth.

Acknowledgements This article is supported by the Centre for Banking and Finance Law, National University of Singapore. We thank Iris Chiu, Virginia E. Harper and Xia Mian for valuable comments on an earlier draft.

\section{References}

An G et al. (2018) Research on global and China’s green funds/国内外绿色基金发展㸴究. China Finance Publishing House, China

Avgouleas E (2021) Resolving the sustainable finance conundrum: activist policies and financial technology. Law Contemp Probl 84:55-73 
Ba S, Cong Y, Zhu W (2019) Analysis of green bond theory and market development in China/绿色债券 理论与中国市场发展分析. J Hangzhou Normal Univ (Soc Sci Edn) 1:91-106

Ba S, Yang C, Yao S (2018) Review of the progress of green finance research in China/中国绿色金融㗑 究进展述评. Finan Dev Res 6:3-11

Black B (2001) The legal and institutional preconditions for strong stock markets: the nontriviality of securities law. UCLA Law Rev 48:781-856

Bond Connect (2021a) About Bond Connect Company Limited (BCCL). https://www.chinabondconnect. com/en/About-Us/Company-Introduction.html. Accessed 31 Nov 2021

Bond Connect (2021b) Trading mechanisms. https://www.chinabondconnect.com/en/Trading/TradingBc/Trading-Mechanism.html. Accessed 31 Nov 2021

Bonds Market Research Team (2021) Lianhe Credit Ratings Report on Green Bonds (2021Q1). China Lianhe Credit Rating Co., Ltd. (WeChat official account), 23 Apr 2021. https://mp.weixin.qq. com/s/E4i83xMXbgddNpVCeCskIA. Accessed 31 Nov 2021

Brown M (2021) 'China's Central Bank Governor outlines green finance priorities'. Lexology, 25 March 2021. https://www.lexology.com/library/detail.aspx?g=29538399-a5db-443c-83ba-7b33c06109 $3 e \& u t m \_s o u r c e=l e x o l o g y+$ daily + newsfeed \&utm_medium $=$ html+email+-+body+-+general+ section\&utm_campaign=lexology+subscriber+daily+feed\&utm_content=lexology+daily+newsf eed+2021-03-26\&utm_term. Accessed 31 Nov 2021

CBI (2017) Facilitating cross-border capital flows to grow the China green bond market. https://www. climatebonds.net/files/reports/china_intracountry_2017-01d_da_en_28nov17_a4.pdf. Accessed 31 Nov 2021

CBI (2019) Climate Bonds Standard Version 3.0. https://www.climatebonds.net/files/files/climate-bondsstandard-v3-20191210.pdf. Accessed 31 Nov 2021

CBI and CCDC Research (2017) China Green Bond Market 2016. https://www.climatebonds.net/resou rces/reports/china-green-bond-market-2016. Accessed 31 Nov 2021

CBI and CCDC Research (2018) China Green Bond Market 2017. https://www.climatebonds.net/resou rces/reports/china-green-bond-market-2017. Accessed 31 Nov 2021

CBI and CCDC Research (2019) China Green Bond Market 2018. https://www.climatebonds.net/resou rces/reports/china-green-bond-market-2018. Accessed 31 Nov 2021

CBI and CCDC Research (2020) China Green Bond Market: 2019 Research Report. https://www.clima tebonds.net/system/tdf/reports/2019_cbi_china_report_en.pdf?file $=1 \&$ type $=$ node $\& i d=47441 \&$ force $=0$. Accessed 31 Nov 2021

CBI and CCDC Research (2021) China Green Bond Market Report 2020. https://www.climatebonds.net/ files/reports/cbi_china_sotm_2021_06d.pdf. Accessed 31 Nov 2021

CBI and SynTao Green Finance (2017) Study of China's local government policy instruments for foreign green bonds. https://www.climatebonds.net/system/tdf/reports/chinalocalgovt_02_13.04_final_a4. pdf?file $=1 \&$ type $=$ node $\&$ id $=31001$. Accessed 31 Nov 2021

CBI and SynTao Green Finance (2020) Report on the Opportunities and Challenges Facing the Issuance of Green Bonds in China/中国的绿色债券发行与机遇报告. https://www.climatebonds.net/resou rces/reports/China_GBIO_CN. Accessed 31 Nov 2021

CGTN (2020) 'China, France vow to promote finance, economic cooperation amid Covid-19 battle', 21 July 2020. https://news.cgtn.com/news/2020-07-21/China-France-vow-to-promote-finance-econo mic-cooperation-SjwhmRhJWU/index.html. Accessed 31 Nov 2021

Chang WF, Amran A, Iranmanesh M, Foroughi B (2019) Drivers of sustainability reporting quality: financial institution perspective. Int J Ethics Syst 35:632-650

Chen J (2021) 'China, EU lead “green revolution” with finance standards', China Daily, 29 Apr 2021. https://www.chinadaily.com.cn/a/202104/29/WS608a0eeca31024ad0babb2c0.html. Accessed 31 Nov 2021

Chen S (2014) Functional positioning of government and market in the commercial law mechanisms/商 法机制中政府与市场的功能定位. China Legal Sci 5:41-59

China Center for International Economic Exchanges (2013) Research on public policies for implementing green development in China. China Economic Press, China

China Central Depository and Clearing Co., Ltd. (2018) Research Report on Green Bond Environmental Benefit Information Disclosure System and Indicator System. https://www.chinabond.com.cn/cb/ cn/yjfx/zybg/20190610/151734197.shtml. Accessed 31 Nov 2021

China Government Securities Depository Trust and Clearing Co. Ltd. and CECEP Consulting Co. Ltd. (2018) Research Report on a Green Bond Environmental Benefit Information Disclosure System 
and Indicator System. https://www.chinabond.com.cn/cb/cn/yjfx/zybg/20190610/151734197. shtml. Accessed 31 Nov 2021

China Green Bonds and Credits (2018) Annual overview of green bonds 2017. Investment Database (WeChat official account), 19 Jan 2018. https://mp.weixin.qq.com/s/1GT6TBksC6Qcl02vd_LflQ. Accessed 31 Nov 2021

Climate Policy Initiative (2020a) MRV system design: recommendations for Chinese green bonds. http:// climatepolicyinitiative.org/wp-content/uploads/2020/06/MRV-System-Design-Recommendationsfor-Green-Bonds-in-China.pdf. Accessed 31 Nov 2021

Climate Policy Initiative (2020b) The state and the effectiveness of the green bond market in China. https://www.climatepolicyinitiative.org/wp-content/uploads/2020/06/The_State_and_Effectinev ess_of_the_Green_Bond_Market_in_China.pdf. Accessed 31 Nov 2021

Coffee J (2007) Law and the market: the impact of enforcement. Univ PA Law Rev 156(2):229-311

Daeniken D (2020) 'Sustainability: investor education can lead to long-term resilient growth', Emerging Market Views, 28 Oct 2020. https://em-views.com/sustainability-investor-education-can-lead-tolong-term-resilient-growth. Accessed 31 Nov 2021

Dai W, Kidney S (2016) Roadmap for China: using green securitisation, tax incentives and credit enhancements to scale green bonds. Climate Bonds Initiative. https://cn.climatebonds.net/files/ files/CBI-IISD-Paper3-EN.pdf. Accessed 31 Nov 2021

Dong X, Liu X, Lin Q (2020) Green Bonds Operation Report 2019-Green bonds market in China continued to improve and the amount of green bonds issuance increased substantially. China Lianhe Credit Rating Co., Ltd. (WeChat official account), 16 March 2020. https://mp.weixin.qq.com/s/ KDiPr9VO6gUpP07xTRC_Dg. Accessed 31 Nov 2021

Dou R, Zhang W (2019) A study on the effect of green factors on bond yield spreads-an analysis based on PSM method / 绿色因子对债券收益利差的影响研究——基于PSM法的分析. J Shanghai LiXin Univ Account Finan 6:47-57

Doyle DH (2021) What is the impact of the EU Sustainable Finance Disclosure Regulation (SFDR)? S\&P Global, 1 Apr 2021. https://www.spglobal.com/marketintelligence/en/news-insights/blog/what-isthe-impact-of-the-eu-sustainable-finance-disclosure-regulation-sfdr. Accessed 31 Nov 2021

Energy Foundation (2020) Climate and Environmental Disclosure Pilot Initiative for UK and China Financial Institutions: 2019 Annual Progress Report. https:/www.efchina.org/Reports-zh/reportlceg-20201103-zh. Accessed 31 Nov 2021

EU Technical Expert Group on Sustainable Finance (2019a) Report on EU Green Bond Standard. https:// ec.europa.eu/info/sites/default/files/business_economy_euro/banking_and_finance/documents/ 190618-sustainable-finance-teg-report-green-bond-standard_en.pdf. Accessed 31 Nov 2021

EU Technical Expert Group on Sustainable Finance (2019b) Taxonomy Technical Report. https://www. ecologic.eu/sites/default/files/publication/2021/3567-190618-sustainable-finance-teg-report-taxon omy_en.pdf. Accessed 31 Nov 2021

Feng G et al. (2019) Green development and green assessment/绿色发展与绿色评估. China Finance Publishing House

Freeburn L, Ramsay I (2020) Green bonds: legal and policy issues. Cap Mark Law J 15(4):418-442

Green Belt and Road Initiative Centre (2021) The Green Investment Principle (GIP) for the Belt and Road Initiative (last updated 30 Apr 2021). https://green-bri.org/green-investment-principle-gipbelt-and-road-initiative/\#: :text=The $\% 20$ Green $\% 20$ Investment $\% 20$ Principle $\% 20(\mathrm{GIP}) \% 20$ is $\%$ 20a\%20set $\% 20$ of $\% 20$ principles,in $\% 20$ the $\% 20$ Belt $\% 20$ and $\% 20$ Road.\&text $=$ As $\% 20$ of $\% 20$ April $\%$ $2025 \% 2 \mathrm{C} \% 202019$,for\%20the\%20Belt\%20and\%20Road. Accessed 31 Nov 2021

Green Bonds Research Team (2021) Green bonds in 2020-a review (second half). China Bonds and Credits (WeChat official account), 27 Jan 2021. https://mp.weixin.qq.com/s/AaebaMEfGltZ2R1 U9v-nQg. Accessed 31 Nov 2021

Green China's Financial System Study Group of DRC (2016) The developmental logic and framework of China's green finance/发展中国绿色金融的逻辑与框架. Financ Forum 2:17-28

Gregory HJ, Palmer H, Wood L (2020) 'Emerging ESG disclosure trends highlighted in GAO Report', Harvard Law School Forum on Corporate Governance, 15 Aug 2020. https://corpgov.law.harvard. edu/2020/08/15/emerging-esg-disclosure-trends-highlighted-in-gao-report/. Accessed 31 Nov 2021

Guo X (2021) Vigorous development of green finance to help achieve the goal of carbon neutrality/大力 发展绿色金融 助力实现碳中和目标. Tsinghua Financ Rev 1:44-46

Harlan T (2019) Green development or greenwashing? A political ecology perspective on China's green Belt and Road. Eurasian Geogr Econ 62(2):202-226 
Hong Y (2010) Multi-pronged regulation, path dependence and future development plan of corporate bonds. Secur Mark Her 4:9-16

Hong Y (2016) Challenges and improvements of green corporate bonds in China/中国绿色公司债券的 制度挑战与改进. Secur Mark Her 9:4-12

Hong Y (2017) International rules and insights on the operational mechanism of green bonds/绿色债券 运作机制的国际规则与启示. Law Sci 2(2):124-134

International Capital Market Association (2018) Green bond principles-voluntary process guidelines for issuing green bonds. https://www.icmagroup.org/assets/documents/Regulatory/Green-Bonds/ Green-Bonds-Principles-June-2018-270520.pdf. Accessed 31 Nov 2021

International Capital Market Association (2021) Impact reporting. https://www.icmagroup.org/sustainable-finance/impact-reporting/. Accessed 31 Nov 2021

International Finance Corporation (2016) Mobilizing private climate finance-green bonds and beyond. https://openknowledge.worldbank.org/bitstream/handle/10986/30351/110881-BRI-EMCompassNote-25-Green-Bonds-FINAL-12-5-PUBLIC.pdf?sequence=1\&isAllowed=y. Accessed 31 Nov 2021

International Institute for Sustainable Development (2016) 'China's G20 Presidency holds green finance, energy sustainability meetings', 22 Feb 2016. http://sdg.iisd.org/news/chinas-g20-presidencyholds-green-finance-energy-sustainability-meetings/. Accessed 31 Nov 2021

IPSF (International Platform on Sustainable Finance) Taxonomy Working Group (Co-chaired by the EU and China) (2021) Common Ground Taxonomy - Climate Change Mitigation. Instruction report, 4 Nov 2021. https://ec.europa.eu/info/sites/default/files/business_economy_euro/banking_and_finan ce/documents/211104-ipsf-common-ground-taxonomy-instruction-report_en.pdf. Accessed 31 Nov 2021

Jiang Y, Lei N (2019) 'Ganjiang New Area issues the first municipal green bond in China', Ganjiang New Area official website, 21 June 2019. http://www.gjxq.gov.cn/art/2019/6/21/art_42022_26601 45.html. Accessed 31 Nov 2021

Jones L (2021) 'Record \$269.5bn green issuance for 2020: late surge sees pandemic year pip 2019 total by \$3bn', Climate Bonds Initiative, 24 Jan 2021. https://www.climatebonds.net/2021/01/record2695bn-green-issuance-2020-late-surge-sees-pandemic-year-pip-2019-total-3bn. Accessed 31 Nov 2021

Kan H (2009) Environment and health in China: challenges and opportunities. Environ Health Prospect 117(12):A530-531

Kidney S, Oliver P, Sonerud B, Climate Bonds Initiative (2015) Chapter 10: greening China's bond market. In: Halle M (ed) Greening China's financial system. International Institute for Sustainable Development, pp 249-253

Latham and Watkins LLP (2021) 'China and EU to collaborate on green investment standards', Lexology, 12 Apr 2021. https://www.lexology.com/library/detail.aspx?g=9031e27b-bc47-4210-b8e5-c4887 8773309\#: :text=The\%20People's\%20Bank\%20of\%20China,two\%20markets\%201ater\%20this\% 20year. Accessed 31 Nov 2021

Lau KY (2020) 'COVID-19: what does it mean for climate change? Lessons from responding to the immediate threat of COVID-19', KPMG. https://home.kpmg/sg/en/home/insights/2020/04/covid19-what-does-it-mean-for-climate-change.html. Accessed 31 Nov 2021

Liao Z, Yun Z (2020) Analysis of green bonds issued overseas by Chinese entities in 2019. Source: International Institute of Green Finance of CUFE. Sina News, 29 July 2020. https://finance.sina.cn/esg/ 2020-07-29/detail-iivhvpwx8120629.d.html. Accessed 31 Nov 2021

Liu T (2018) Where does China fall short in cultivating green bond investors?/培育绿色债券投资者, 中 国还差在哪里? China Bank 6:108-110

Lu W (2020) Comparative analysis of standardization and consistency in green finance standards between China and Europe/中欧绿色金融标准一致性的比较与分析. China Bonds 4:75-80

Lu W, Wang Y (2016) Seeking a clear definition of green bonds projects/明确界定绿色债券项目. China Financ 6:54-55

Ma J (2016) Building a theoretical framework for green finance. Financ Mark Res 2:2-8

Ma J (2017) Green finance and the role of government, UN Environment Programme, 13 Oct 2017. https://unepinquiry.org/blogs/green-finance-and-the-role-of-government/. Accessed 31 Nov 2021

Ma J (2019) Preface for green finance series/《绿色金融丛书》序言. In: Jin H (ed) Research on green finance evaluation system—green evaluation of enterprises, assets and supply chain / 绿色金融评 价体系硎究——企业, 资产与供应链的绿色评价. China Finance Publishing 
Ma J (2021) 'Improving the green financial system with the goal of carbon neutrality', Financial Times, 18 Jan 2021. https://h5.newaircloud.com/detailArticle/15048522_28236_jrsb.html?app=1\& source $=1$. Accessed 31 Nov 2021

Ma J, Liu J, Chen Z, Xie W (2019) Chapter 7: green bonds. In: Schipke A, Rodlauer M, Zhang L (eds) The future of China's bond market. International Monetary Fund

Ma J et al. (2020) How to construct a financial service system that supports green technological innovation/构建支持绿色技术创新的金融服务体系. China Finance Publishing House

Ma M (2020) 'Harmonization of domestic green bond standards praised by international authorities', Hexun.com, 10 July 2020. http://bank.hexun.com/2020-07-10/201686705.html. Accessed 31 Nov 2021

MacLeod M, Park J (2011) Financial activism and global climate change: the rise of investor-driven governance networks. Global Envtl Pol 11:54-74

Mai J, Xu F (2015) Research on the impact factors of green finance in China based on joint analysis/基于 联合分析的我国绿色金融影响因素㸴究. Macroecon Res 5:23-27

Myers SL (2020) 'China's pledge to be carbon neutral by 2060: what it means', The New York Times, 23 Sep 2020. https://www.nytimes.com/2020/09/23/world/asia/china-climate-change.html. Accessed 31 Nov 2021

National Association of Financial Market Institutional Investors (2021a) Innovative launch of carbon neutral bonds to help achieve the 30-60 goals/创新推出碳中和债, 助力实现30/60目标. http://www. nafmii.org.cn/xhdt/202102/t20210209_84483.html. Accessed 31 Nov 2021

National Association of Financial Market Institutional Investors (2021b) Statistics on the volume of debt financing instruments in 2020/2020年债务融资工具业务量统计. http://www.nafmii.org.cn/ scyjfx/ywltj/202101/P020210121612536685896.pdf. Accessed 31 Nov 2021

National Development and Reform Commission (2021) Press Conference of 19 July 2021 on macroeconomic conditions and other important topics/国家发展改革委举行7月份新闻发布会 介绍宏观 经济运行情况并回应热点问题, 19 July 2021. https://www.ndrc.gov.cn/xwdt/xwfb/202107/t2021 0719_1290743.html?code=\&state=123. Accessed 31 Nov 2021

Network for Greening the Financial System (2020) Overview of environmental risk analysis by financial institutions. https://www.ngfs.net/sites/default/files/medias/documents/overview_of_environmen tal_risk_analysis_by_financial_institutions.pdf, and case studies of environmental risk analysis methodologies. https://www.ngfs.net/en/case-studies-environmental-risk-analysis-methodologies. Both accessed 31 Nov 2021

Ng E (2021) 'Earth Summit 2021: China excludes fossil fuel projects from green bonds, taking a step towards global standards on the path to 2060', South China Morning Post, 22 Apr 2021. https:// www.scmp.com/business/companies/article/3130643/earth-summit-2021-fossil-fuel-exclusionchinese-green-bonds. Accessed 31 Nov 2021

Park S (2018) Investors as regulators: green bonds and the governance challenges of the sustainable finance revolution. Stanf J Int Law 54:1-47

People.cn (2017) 'Jiangsu: "Green GDP" formally included in the appraisal report for officials published to the public', 5 Sept 2017. http://politics.people.com.cn/n1/2017/0905/c1001-29514670.html. Accessed 31 Nov 2021

People's Bank of China (2017) Joint announcement of the People's Bank of China and Hong Kong Monetary Authority, 2 July 2017. http://www.pbc.gov.cn/en/3688110/3688181/3699007/index.html. Accessed 31 Nov 2021

People's Bank of China (2021a) Transcript of the briefing on green finance at the State Council Information Office of China, 9 Feb 2021. http://www.pbc.gov.cn/goutongjiaoliu/113456/113469/4191657/ index.html. Accessed 31 Nov 2021

People's Bank of China (2021b) 'Governor Yi Gang attended the PBC-IMF High-Level Seminar on Green Finance and Climate Policy and delivered opening remarks', Hong Kong Green Finance Association, 16 Apr 2021. https://www.hkgreenfinance.org/governor-yi-gang-attended-the-pbcimf-high-level-seminar-on-green-finance-and-climate-policy-and-delivered-opening-remarks/. Accessed 31 Nov 2021

People's Bank of China Research Bureau (2019) China green finance development report 2018. China Finance Press

Qian L, Lu Z (2018) New opportunities and challenges in China's green bonds market. China Bank 9:83-85 
Renewables Now (2015) 'Update 1-Goldwind's USD-300m green bond 5 times oversubscribed', Renewables Now, 21 July 2015. https://renewablesnow.com/news/update-1-goldwinds-usd-300mgreen-bond-5-times-oversubscribed-484885/. Accessed 31 Nov 2021

Shanghai Branch of the State Administration of Foreign Exchange (2020) Green finance and low-carbon development_-Video speech by Yi Gang, Governor of the People's Bank of China, at the Singapore Fintech Festival. http://www.safe.gov.cn/shanghai/2020/1210/1420.html. Accessed 31 Nov 2021

Shenzhen Municipal Financial Regulatory Bureau (2021) 'Shenzhen Special Economic Zone Green Finance Regulations came into effect', 2 March 2021. http://jr.sz.gov.cn/sjrb/xxgk/gzdt/content/ post_8577732.html. Accessed 31 Nov 2021

Shi Y (2019) Green Finance International Research Institute's China Green Bond Market Development Report 2019/中央财经大学绿色金融国际㸴究院《中国绿色债券市场发展报告 (2019)》. China Finance Press

Shi Y, Wang Y (2018) Green bonds. China Financial Press

Sina News (2005) 'Environmental performance assessment of leading officials pilot this year', 17 March 2005. https://news.sina.com.cn/c/2005-03-17/08025383989s.shtml. Accessed 31 Nov 2021

Standard Chartered (2020) Standard Chartered Sustainable Investing Review 2020 - Growing sustainable investments through knowledge. https://av.sc.com/corp-en/content/docs/Sustainable-InvestingReview-2020.pdf. Accessed 31 Nov 2021

State Administration of Foreign Exchange (2020) 'PBOC \& SAFE remove QFII/RQFII investment quotas and promote further opening-up of China's financial market', 7 May 2020. https://www.safe. gov.cn/en/2020/0507/1677.html. Accessed 31 Nov 2021

State Council (2021) 'China's GDP tops 100 trillion yuan in 2020', 18 Jan 2021. http://english.www.gov. cn/archive/statistics/202101/18/content_WS60052129c6d0f72576944049.html. Accessed 31 Nov 2021

Supreme People's Court (2021) 'Zhou Qiang: promote environmental rule of law and the harmonious coexistence between human beings and nature', Supreme People's Court, 26 May 2021. http://www. court.gov.cn/zixun-xiangqing-305331.html. Accessed 31 Nov 2021

Sustainability Accounting Standards Board (2021) Download SASB Standards. https://www.sasb.org/ standards/download/. Accessed 31 Nov 2021

SWITCH Asia (2019) International Platform on Sustainable Finance (IPSF). https://www.switch-asia.eu/ resource/international-platform-on-sustainable-finance-ipsf/\#: :text=The $\% 20$ International $\% 20 \mathrm{Pla}$ tform $\% 20$ on $\% 20$ Sustainable,the\%20world's\%20greenhouse $\% 20$ gas $\% 20$ emissions. Accessed 31 Nov 2021

Ting C (2020) 'Has Xi Jinping's anti-corruption campaign been effective? China's land transactions provide one answer', South China Morning Post, 20 Aug 2020. https://www.scmp.com/comment/opini on/article/3097830/has-xi-jinpings-anti-corruption-campaign-been-effective-chinas-land. Accessed 31 Nov 2021

UK Treasury (2019) UK-China 10th Economic and Financial Dialogue: policy outcomes. https://www. gov.uk/government/publications/uk-china-10th-economic-and-financial-dialogue-policy-outcomes. Accessed 31 Nov 2021

United Equator Bonds Research Institute (2020) 2019 Report on Green Bonds in China/2019年绿色债券 运行报告. http://www.lianhecreditrating.com.cn/userfiles/2019\%E5\%B9\%B4\%E5\%BA\%A6\%E7\%

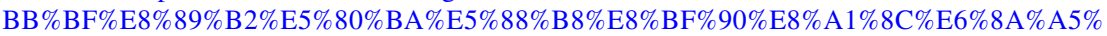
E5\%91\%8A.pdf. Accessed 31 Nov 2021

UN Partnership for Action on Green Economy (2016) 'The People's Bank of China issued the "Guidelines for Establishing the Green Financial System”,', 31 Aug 2016. https://www.un-page.org/ people $\%$ E2\%80\%99s-bank-china-issued-\%E2\%80\%9Cguidelines-establishing-green-financial-system\%E2\%80\%9D. Accessed 31 Nov 2021

UNPRI (2019) UK-China Climate and Environmental Information Disclosure Pilot-2019 Progress Report. https://www.unpri.org/download?ac=10546. Accessed 31 Nov 2021

US Government Accountability Office (2020) Public companies. Disclosure of environmental, social and governance factors and options to enhance them. https://www.gao.gov/assets/gao-20-530.pdf. Accessed 31 Nov 2021

Wang C (2021) 'What can environmentally conscious judiciary do to support green finance', China Environmental News, 19 March 2021. https://www.cenews.com.cn/opinion/plxl/202103/t20210319_ 972072.html. Accessed 31 Nov 2021 
Wang CN, Huang H (2021) Interpretation of guiding opinions on green and low-carbon circular development (State Council, February 2021), 27 Feb 2021. https://green-bri.org/interpretation-of-guidingopinions-on-green-and-low-carbon-circular-development-state-council-february-2021/. Accessed 31 Nov 2021

Wang Y, Ma Q (2020) Local green finance development index and assessment report 2019/地方绿色金 融发展指数与评估报告 (2019). China Finance Publishing House

Whiley A (2018) 'Chinese regulators introduce supervisory scheme for green bond verifiers-further step in building market frameworks', Climate Bonds Initiative, 15 Jan 2018. https://www.climatebonds. net/2018/01/chinese-regulators-introduce-supervisory-scheme-green-bond-verifiers-further-stepbuilding. Accessed 31 Nov 2021

Wilkins RC (2021) 'China urges "market forces” to fill gap in green bond program', 22 March 2021. https://www.bloomberg.com/news/articles/2021-03-22/china-urges-market-forces-to-fill-gap-ingreen-bond-program. Accessed 31 Nov 2021

World Resources Institute (2020) 'Statement: China commits to stronger climate targets at Climate Ambition Summit', World Resources Institute, 12 Dec 2020. https://www.wri.org/news/statement-chinacommits-stronger-climate-targets-climate-ambition-summit. Accessed 31 Nov 2021

Xiao J, Yan X (2018) Status quo and comparative analysis of green finance standards and recommendations/绿色金融标准体系现状, 国际比较及建议. Financ Perspect J 5:81-87

Xinhua News (2017) 'China's first green development index released to evaluate the quality of development in local regions’, 26 Dec 2017. http://www.stats.gov.cn/tjsj/sjjd/201712/t20171226_1567038. html. Accessed 31 Nov 2021

Xinhua News (2019) 'Li Keqiang leads the meeting of National Leading Group to address climate change, energy saving and emission reduction', 11 July 2019. http://www.xinhuanet.com/politics/ 2019-07/11/c_1124741769.htm. Accessed 31 Nov 2021

Xinhua News (2021a) 'The Shenzhen Special Economic Zone Green Finance Regulations came into effect, 1 Mar 2021. http://www.gd.xinhuanet.com/newscenter/2021-03/01/c_1127153864.htm. Accessed 31 Nov 2021

Xinhua News (2021b) 'Shenzhen launches the GEP accounting “1+3” system', 24 Mar 2021. http://www. szzengjin.com/caij/214103.html. Accessed 31 Nov 2021

Xinhua News (2021c) 'Coal and other fossil-based energy clean use projects will no longer be included in the scope of green bonds', 22 Apr 2021. http://www.xinhuanet.com/2021-04/22/c_1127358663. htm. Accessed 31 Nov 2021

Xu T, Su F (2020) 'Providing judicial support for green finance and environmental protection', Xinhua Finance, 29 Apr 2020. http://greenfinance.xinhua08.com/a/20200429/1933781.shtml. Accessed 31 Nov 2021

Yeung K (2021) 'China's opening of Hong Kong bond market for mainlanders signals Beijing hastening efforts to open capital account', South China Morning Post, 5 May 2021. https://www.scmp.com/ economy/china-economy/article/3132379/chinas-opening-hong-kong-bond-market-mainlanderssignals. Accessed 31 Nov 2021

Yi G (2020) Supporting low carbon development with green finance. Speech at the Singapore FinTech Festival, Bank for International Settlements, 9 Dec 2020. https://www.bis.org/review/r201222g. htm. Accessed 31 Nov 2021

Yin H (2020) Development of global green classification standards/全球绿色分类标准及发展. China Financ 9:65-67

Yun Z (2021) China's Green Bond Market 2020 Annual Analysis Brief. International Institute of Green Finance, Central University of Finance and Economics (WeChat official account), 19 Jan 2021. https://mp.weixin.qq.com/s/_pMK6aphJSOK2E7gtnWHiw. Accessed 31 Nov 2021

Zhang H (2020) Regulating green bonds in the People's Republic of China: definitional divergence and implications for policy making. ADBI Working Paper 1072.

Zheng Y (2016) The current situation and prospects of China's green bond development in the context of economic transformation. Contemp Econ Manag 6:77-78

Zhou Q (2021) Strengthening environmental rule of law for sustainable development. Speech prepared for delivery at the World Judicial Conference. UN Environmental Programme, 26 May 2021. https://www.unep.org/news-and-stories/speech/strengthening-environmental-rule-law-sustainabledevelopment. Accessed 31 Nov 2021 
Publisher's Note Springer Nature remains neutral with regard to jurisdictional claims in published maps and institutional affiliations.

\section{Authors and Affiliations}

\section{Lin Lin ${ }^{1} \cdot$ Yanrong Hong ${ }^{2}$}

1 Associate Professor, Faculty of Law, National University of Singapore, Singapore, Singapore

2 Associate Professor, School of Law, Peking University, Beijing, China 